\title{
Physical forcing of phytoplankton community structure and primary production in continental shelf waters of the Western Antarctic Peninsula
}

\author{
by B. B. Prézelin ${ }^{1}$, E. E. Hofmann ${ }^{2}$, M. Moline ${ }^{3}$ and J. M. Klinck ${ }^{2}$
}

\begin{abstract}
Analyses of a multidisciplinary data set, collected in continental shelf waters of the Western Antarctic Peninsula (WAP) during austral summer of January 1993, identified a previously unrecognized forcing mechanism that sets up a physical and chemical structure that supports and assures site-specific diatom-dominated communities and enhanced biological production (Prézelin $e t$ al., 2000). This forcing is active when the southern boundary of the Antarctic Circumpolar Current (ACC) flows along the shelf edge, thereby facilitating onshelf bottom intrusions of nutrient-rich Upper Circumpolar Deep Water (UCDW), which then is upwelled or mixed into the upper water column. At times or locations where UCDW is not introduced to the upper water column, diatoms no longer dominate phytoplankton assemblages over the mid- to outer WAP continental shelf. This analysis extends the area and seasons studied through similar analyses of multidisciplinary data sets collected on four additional cruises to the WAP that cover all seasons. Results show that onshelf intrusions of UCDW: (1) occur in other regions of the WAP continental shelf; (2) are episodic; (3) are forced by nonseasonal physical processes; and (4) produce areas of diatom-dominated phytoplankton assemblages and enhanced primary production. At times, multiple intrusions are observed on the WAP continental shelf, and each event may be in a different stage. Further, the occurrence of an intrusion event in one area does not necessarily imply that similar events are ongoing in other areas along the WAP shelf. The UCDW bottom intrusions originate along the outer shelf but they can extend into the inner shelf region because the deep troughs that transect the WAP shelf provide connections between the inner and outer shelf. The boundary between the intruded water and the shelf water is variable in location because of the episodic nature of the onshelf intrusions, and is moved farther inshore as an event occurs. These observations show clearly that the phytoplankton community structure on the WAP shelf is determined by physical forcing and that primary production is likely to be considerably greater than previously believed. Moreover, variability in this physical forcing, such as may occur via climate change, can potentially affect the overall biological production of the WAP continental shelf system.
\end{abstract}

1. Marine Science Institute and Department of Ecology, Evolution and Marine Biology, University of California, Santa Barbara, California, 93106, U.S.A. email: prezelin@lifesci.ucsb.edu

2. Center for Coastal Physical Oceanography, Old Dominion University, Norfolk, Virginia 23529, U.S.A.

3. Biological Sciences Department, California Polytechnic State University, San Luis Obispo, California, 93407, U.S.A. 







\section{Introduction}

Coincident environmental and biological data sets collected in January 1993, in continental shelf waters of the Western Antarctic Peninsula (WAP) (Fig. 1), were used to describe a previously unrecognized mechanism that sets up a physical and chemical structure that supports enhanced biological production (Prézelin et al., 2000). This mechanism is provided by onshelf subsurface intrusions of warm $\left(>1.5^{\circ} \mathrm{C}\right)$ Upper Circumpolar Deep Water (UCDW), which then upwells and/or is mixed upward, introducing elevated concentrations of nutrients and potentially other constituents, such as trace metals, into the upper water column. Diatom-dominated phytoplankton assemblages, forming subsurface chlorophyll $a$ maxima above the pycnocline, characterize the regions where UCDW is mixed into the surface waters. Other phytoplankton taxa dominate outside of these areas (Fig. 1). In addition, the distribution of higher trophic level consumers, such as Antarctic krill (Euphausia superba), is influenced by UCDW intrusions (Prézelin et al., 2000). The diatom-dominated communities develop largely below optical depths used in satellite detection and do not conform to remote sensing assumptions of correlation between detectable surface chlorophyll $a$ and deeper chlorophyll $a$ (Moline and Prézelin, 2000). The UCDW-influenced diatom-dominated communities that develop over the outer continental shelf are subject to advection off the shelf during intrusion events and to aggregation and sedimentation following events. These observations led Prézelin et al. (2000) to suggest that the physical environment is a primary factor structuring the phytoplankton community composition in WAP continental shelf waters and that biooptical methods may underestimate primary production of regions influenced by UCDW. The dynamics of the coupled bio-optical and biological-physical controls of primary production in this physically forced system during January 1993 has been modeled and indicates that the production potential of diatom-dominated communities could be underes-

Figure 1. (a) Map of the Western Antarctic Peninsula and sites where comparable data sets were collected over the same region of the continental shelf during five cruises that occurred in November 1991, January 1993, March 1993, August 1993, and January 1994 (shaded box parallel to coastline). The findings are placed in a larger context by comparison with observations from other regions of the Antarctic, including cross-shelf transects made in the vicinity of the Bransfield Strait during the Korean survey cruise in the austral summer of 1993 (Kang and Lee, 1995) and north-south transects across the marginal ice zone in the Bellingshausen Sea at $72 \mathrm{~W}$, beyond the continental shelf, surveyed on the austral spring cruise of Icecolors '90 (Prézelin et al., 1994). (b) Summary of dominant phytoplankton community composition overlaid on the temperature maxima (Tmax) distribution below $250 \mathrm{~m}$ for the January 1993 cruise. The diatom-dominated communities are comprised of $>60 \%$ diatoms; phytoflagellate-dominated communities are comprised of $>60 \%$ prymnesiophytes + pelagophytes; and mixed communities are those in which no algal group was $>60 \%$. Sites where intrusions of Upper Circumpolar Deep Water (UCDW) were observed in January 1993 are indicated by the gray arrows. Wind-induced upwelling and bathymetrically-induced mixing sites of UCDW are indicated by the black and clear arrows, respectively (from Prézelin et al., 2000). 
timated by more than two fold in the absence of consideration of carbon loss due to across-shelf and vertical advection, especially off the shelf on the outer shelf, and due to zooplankton grazing, especially on the inner shelf (Kim et al., 2003).

The mechanisms by which UCDW intrusions occur were examined using a circulation model developed for the WAP continental shelf (Dinniman and Klinck, 2004). Analyses of the simulated circulation fields showed a significant correlation between the curvature of the shelf break and the volume of UCDW transported across the shelf break. The simulation results show that onshelf movement of UCDW occurs at sites where the Antarctic Circumpolar Current (ACC), which flows along the outer WAP shelf, encounters variations in the topography of the shelf break.

Intrusions of UCDW onto the Antarctic continental shelf can set up regions of enhanced localized biological production. However, the biological effects of UCDW intrusions described in Prézelin et al. (2000) refer to a time in the austral summer when the WAP continental shelf is free of sea ice, light is available, herbivore grazing is potentially at a maximum, surface mixed layers and a seasonal pycnocline exist, and surface water temperatures are at an annual maximum. Thus, for this physical forcing mechanism to be considered a primary determinant of annual biological production in Antarctic continental shelf waters, its occurrence at other times of the year and at other sites needs to be demonstrated.

In this study, hydrographic, nutrient, phytoplankton community composition, and primary production distributions from four additional cruises to the WAP shelf (Table 1) are used to describe UCDW intrusions and their effects. These additional data sets extend the spatial domain along the WAP continental shelf, cover all seasons, and provide a repeat realization of the austral summer. Four of the five cruises occurred in the same year, which allows assessment of environmental and biological changes on time scales of a few weeks to months. Section 4 of the paper summarizes the characteristics of UCDW intrusions, considers the effect of intrusions on nonseasonal succession in phytoplankton communities and highlights the importance of these events for biological production and carbon partitioning in Antarctic continental shelf waters. Section 6 provides suggestions for why UCDW intrusions and associated biology have been unrecognized on the Antarctic continental shelf and addresses the potential implications of these events for biological production of Antarctic coastal waters.

\section{Methods}

\section{a. Study area}

The same region of the WAP continental shelf was sampled during four cruises that took place between January 1993 and January 1994 and a fifth cruise that occurred in November 1991 (Table 1). Hydrographic and biological samples were collected at fixed station locations aligned in across-shelf transects from the inner shelf to offshore of the shelf break (Fig. 2). Station spacing was $20 \mathrm{~km}$ along transects and $100 \mathrm{~km}$ between transects. From 
Table 1. Summary of cruise dates, duration, daylengths, transects surveyed on the Palmer LTER sample grid, total area surveyed, numbers of CTD and biological stations, and numbers of pigment, inorganic nutrient and photosynthesis-irradiance (P-I) curves at different locations and depths considered in the present analyses. Replicate samples are part of the analyses but they are not included in the numbers listed here. Additional samples collected off transect lines or to determine diel variations are not part of the analyses but employed as a frame of reference.

Across-

\begin{tabular}{|c|c|c|c|c|c|c|c|c|c|}
\hline $\begin{array}{l}\text { Cruise dates } \\
\text { and season }\end{array}$ & $\begin{array}{l}\text { Cruise } \\
\text { length } \\
\text { (days) }\end{array}$ & $\begin{array}{l}\text { Daylength } \\
\text { (hrs) }\end{array}$ & $\begin{array}{c}\text { shelf } \\
\text { transects } \\
\text { sampled* }\end{array}$ & $\begin{array}{c}\text { Area } \\
\text { covered } \\
\left(\mathrm{km}^{2}\right)\end{array}$ & $\begin{array}{c}\text { CTD } \\
\text { stations }\end{array}$ & $\begin{array}{c}\text { Biological } \\
\text { sampling } \\
\text { stations }\end{array}$ & $\begin{array}{c}\text { HPLC } \\
\text { samples }\end{array}$ & $\begin{array}{l}\text { Nutrient } \\
\text { samples }\end{array}$ & $\begin{array}{c}\text { P-I } \\
\text { curves }\end{array}$ \\
\hline $\begin{array}{l}8 \text { Jan. to } 8 \\
\text { Feb } 93 \\
\text { (summer) }\end{array}$ & 31 & 20 to 17.3 & $200-600$ & 80,000 & 47 & 40 & 435 & 586 & 461 \\
\hline $\begin{array}{l}25 \text { Mar to } \\
15 \text { May } 93 \\
\text { (fall) }\end{array}$ & 51 & 7.8 to 11 & 000-800 & 180,000 & 155 & 79 & 643 & 643 & 186 \\
\hline $\begin{array}{c}23 \text { Aug. to } 30 \\
\text { Sept } 93 \\
\text { (winter) }\end{array}$ & 38 & 9.8 to 11.8 & $200-600$ & 60,000 & 42 & 39 & 291 & 360 & 90 \\
\hline $\begin{array}{l}11 \text { Jan to } \\
7 \text { Feb } 94 \\
\text { (summer) }\end{array}$ & 27 & 19.3 to 16.4 & $300-600$ & 54,000 & 48 & 32 & 247 & 323 & 266 \\
\hline $\begin{array}{l}7 \text { Nov to } \\
21 \text { Nov } 91 \\
\text { (spring) }\end{array}$ & 14 & 17.9 to 18.6 & $500-700$ & 20,000 & 27 & 26 & 244 & 265 & 250 \\
\hline
\end{tabular}

north to south, transects were numbered from 800 to 000. Details of sampling strategies for individual cruises are given in Lascara et al. (1993a,b), Smith et al. (1993a,b), and Prézelin et al. (2000).

For the analyses presented in the following sections, the study area was divided into outer, mid- and inner shelf regions. The outer region includes the shelf area that is within about $50 \mathrm{~km}$ of the continental shelf break at 500 to $700 \mathrm{~m}$ depth and is directly affected by the ACC. The mid-shelf region is between $50 \mathrm{~km}$ and $100 \mathrm{~km}$ of the continental shelf break. The inner shelf refers to those regions more than $100 \mathrm{~km}$ from the continental shelf break.

\section{b. Hydrographic samples}

Conductivity-temperature-depth (CTD) measurements were made using a SeaBird 911+ CTD system. On November 1991, January 1993, August 1993 and January 1994 cruises, the CTD system was mounted on a bio-optical profiling system, which limited the vertical profiles to $500 \mathrm{~m}$, but for most stations, this depth exceeded or was near the bottom. For the March-May cruise, the CTD system was separate from the bio-optical profiling 



Figure 2. Comparison of the horizontal distribution of the temperature maximum (Tmax) below 200 m for (a) January-February 1993, (b) March-May 1993, (c) August-September 1993, (d) January-February 1994, and (e) November 1991. Filled circles indicate the distribution of the stations at which the CTD measurements were made. Temperatures ranged from $<1.0^{\circ} \mathrm{C}$ (palest gray) to $\geq 1.8^{\circ} \mathrm{C}$ (yellow). (f) Bathymetry ( $2000 \mathrm{~m}$, $1000 \mathrm{~m}, 500 \mathrm{~m}$ ) of the study region. 
system and casts were made to within a few meters of the bottom at all stations. Complete descriptions of the sensor calibrations and data processing are given in Lascara et al. (1993a,b), Smith et al. (1993a,b), and Klinck and Smith (1994).

\section{c. Nutrient samples}

Water samples were collected at discrete depths using either 5-L Go-Flo bottles or 10-L Niskin bottles, filtered through a $4 \mu \mathrm{m}$ polycarbonate filter and the filtrate frozen at $-20^{\circ} \mathrm{C}$. Nutrient determinations for nitrate, silicate and phosphate samples collected during November 1991, January 1993 and 1994, and August 1993 were done at the Marine Science Analytical Laboratories, University of California Santa Barbara, according to the methods of Johnson et al. (1985). Nutrient samples collected during March-May 1993 were analyzed during the cruise using the same methods.

\section{d. Pigment samples and estimation of phytoplankton community structure}

Pigment determinations were made at sea using reverse-phase HPLC procedures (Prézelin et al., 2000). The regression and validation procedures used for calculations of the distribution of chlorophyll ( $\mathrm{Chl} a$ ) biomass among the different phytoplankton groups known to be present are the same as those detailed in Prézelin et al. (2000). Chlorophyll $b(\mathrm{Chl} b), 19$ '-hexanoyloxy-fucoxanthin (HEX-FUCO), 19'-butanoyloxyfucoxanthin (BUT-FUCO), fucoxanthin (FUCO), peridinin (PER), and alloxanthin (ALLO) are the biomarkers for chlorophytes, prymnesiophytes, pelagophytes, diatoms, dinoflagellates and cryptophytes, respectively. In this analysis, HEX-FUCO was combined with BUT-FUCO to provide a single chemotaxonomic marker for what is termed "phytoflagellates," which represents the combined populations of prymnesiophytes + pelagophytes; nanoplankton that generally co-occur throughout much of Southern Ocean.

\section{e. Photosynthesis-irradiance relationships}

Photosynthesis-irradiance (P-I) curves for carbon fixation were determined as detailed in Boucher and Prézelin (1996) and P-I parameters derived using equations of Neale and Richerson (1987). Measurements of in situ $\mathrm{Q}_{\mathrm{PAR}}$ are not available and thus analyses are presently limited to assessing patterns of mid-day and daily integrated potential carbon production (volumetric $\mathrm{P}_{\mathrm{MAX}}$ ) and assimilation rates (Chl $a$-specific $\mathrm{P}_{\mathrm{MAX}}$ ), a proxy for photosynthetic growth potential. Only findings from the P-I determinations measured as radiolabel ${ }^{14} \mathrm{C}$ uptake in the upper $60 \mathrm{~m}$ around solar noon are compared and the potential impact of diel variations in P-I are not considered here (however, see Kim et al., 2003; Mizerek and Prézelin, 2004). Our preliminary estimates of daily rates of integrated primary production are based upon knowledge of day-length for each station and assuming that the average hourly production over the day is about 0.6 that of mid-day rates of primary production. 


\section{Results}

\section{a. Temperature maximum below $200 \mathrm{~m}$}

As UCDW approaches the Antarctic continental shelf, it shoals to 150-200 m along the outer shelf edge (Sievers and Nowlin, 1984; Jacobs, 1991; Whitworth et al., 1998). Along the WAP where conditions are favorable, this water mass moves onshore and floods the continental shelf below 200 m (Hofmann and Klinck, 1998; Smith et al., 1999) (Fig. 2a). The movement of UCDW across the WAP continental shelf can be traced by the distribution of the temperature maximum (Tmax) below $200 \mathrm{~m}$ (Fig. 2). Temperatures $>1.5^{\circ} \mathrm{C}$ are associated with newly intruded UCDW and the southern boundary of the ACC is associated with the $1.8^{\circ} \mathrm{C}$ isotherm at $200 \mathrm{~m}$ (Orsi et al., 1995). Temperatures of $1.5^{\circ} \mathrm{C}-1.3^{\circ} \mathrm{C}$ are associated with modified UCDW, which is produced by mixing of UCDW and Antarctic Surface Water (AASW) (Smith et al., 1999). The rate of cooling of UCDW is such that it takes 2-3 months to reach temperatures characteristic of modified UCDW (Klinck, 1998; Smith et al., 1999; Smith and Klinck, 2002). Temperatures $<1.3^{\circ} \mathrm{C}$ represent inner shelf water. In January 1993 (Fig. 2a), the southern boundary of the ACC was located along the outer edge of all transects with the exception of Transect 300 where the ACC was displaced farther offshore. Extending onto the shelf $\geq 100 \mathrm{~km}$ on either side of Transect 300 was a large intrusion of UCDW that reached to the inner shelf along Transect 400. The isotherm pattern during the austral summer of 1993 (Fig. 2a) suggested that the UCDW intrusion to the mid-shelf region of Transects 300-400 displaced modified UCDW from a prior event to the inner shelf.

The temperature maximum distribution approximately two months later (Fig. 2b) showed the southern boundary of the ACC along the outer shelf and onshelf movement of UCDW over a $400 \mathrm{~km}$ region of shelf between Transects 000 and 400. Modified UCDW was found over most of the mid- and inner shelf. Colder water $\left(<1.3^{\circ} \mathrm{C}\right)$ on the inner part of Transects 700-800 is derived from outflow from the Gerlache Strait and is associated with a southerly flowing coastal current that is found along the inner portion of the WAP continental shelf (Smith et al., 1999).

Sea ice was present over the entire region sampled in mid-winter, August 1993 (Fig. 2c). The southern boundary of the ACC was located just off the edge of the continental shelf with a small region of onshore movement of UCDW toward the mid-shelf occurring once again at Transect 300. Most of the remaining outer, mid- and inner shelf of Transects 200-600 were covered with modified UCDW. A small isolated region of temperatures $>1.5^{\circ} \mathrm{C}$ was observed at mid-shelf on Transect 500 .

By January 1994 (Fig. 2d), the next austral summer, UCDW was found only along the $300 \mathrm{~km}$ of the outer shelf sampled between Transects 300 and 600. No UCDW intrusions were evident on the WAP continental shelf at this time, in striking contrast to physical conditions the previous summer (Fig. 2a). Rather, with the exception of a small patch of $1.5^{\circ} \mathrm{C}$ water in a part of the mid-shelf region on Transect 500, modified UCDW covered the entire mid-shelf regions between Transects 300 and 600 in the austral summer of 1994.

Observations during the austral spring, November 1991, were limited and the across- 
shelf transects did not extend far enough offshore to resolve the location of the southern boundary of the ACC (Fig. 2e). Heavy sea ice covered the study region, with the exception of a region of open water in Dallmann Bay on the inner part of Transect 700. UCDW was present at the outer shelf of Transect 700, near the edge of the marginal ice zone (MIZ). Within the MIZ, the shelf was covered by modified UCDW as were the mid- and inner shelf regions.

\section{b. Silicate to nitrate ratio at $200 \mathrm{~m}$}

Unmodified UCDW has a silicate to nitrate $\left[\mathrm{Si}(\mathrm{OH})_{4}: \mathrm{NO}_{3}\right]$ ratio between 3.0 and 3.5 (Smith et al., 1999) and this ratio might be expected below $200 \mathrm{~m}$ when UCDW intrusions are present on the shelf of the Western Antarctic Peninsula. However, observations show considerable variability in the $200 \mathrm{~m}$ distribution of the $\mathrm{Si}(\mathrm{OH})_{4}: \mathrm{NO}_{3}$ ratio in regions where the temperature distributions indicate that UCDW intrusions have occurred (Fig. 3). Reduction in the ratio is an indication of prior and/or ongoing biological processing of this UCDW. The lowered $\mathrm{Si}(\mathrm{OH})_{4}: \mathrm{NO}_{3}$ ratio is attributable to preferential utilization of silicate with respect to nitrate (e.g. Prézelin et al., 2000), which takes place near the pycnocline as low light adapted diatoms respond to the UCDW (see below).

In January 1993, lowest $\mathrm{Si}(\mathrm{OH})_{4}: \mathrm{NO}_{3}$ ratios at $200 \mathrm{~m}(<2.0$, Fig. 3a) coincided with the onshore intrusion of UCDW between Transects 200 and 400 (Fig. 2a). In areas where UCDW intrusions were present and diatoms dominated, the $\mathrm{Si}(\mathrm{OH})_{4}: \mathrm{NO}_{3}$ ratios in the upper $100 \mathrm{~m}$ averaged about 1.7 (Table 2). The lowering of the $\mathrm{Si}(\mathrm{OH})_{4}: \mathrm{NO}_{3}$ ratio from a base value of ca. 3.0 for $\mathrm{UCDW}$ was due to preferential removal of $\mathrm{Si}(\mathrm{OH})_{4}$ relative to $\mathrm{NO}_{3}$ (Prézelin et al., 2000). The highest water column $\mathrm{Si}(\mathrm{OH})_{4}: \mathrm{NO}_{3}$ ratio detected was 3.05 at a mid-shelf station on Transect 500 sampled two days after a major storm event (Prézelin et al., 2000) and before significant biological processing occurred. The newly upwelled waters were characterized by the uncommon prevalence of chlorophytes mixed with an abundance of diatoms (Prézelin et al., 2000). For five stations on Transects 500 and 600, where chlorophytes were $>15 \%$ of the chlorophyll $a$, recent UCDW upwelling was indicated by the hydrographic measurements and the $\mathrm{Si}(\mathrm{OH})_{4}: \mathrm{NO}_{3}$ ratios $>2.6$ for the upper $100 \mathrm{~m}$ (Table 2). Four stations were sampled at the outflow of the Gerlache Strait that were not influenced by UCDW and at these sites phytoflagellate-dominated communities were observed and water column $\mathrm{Si}(\mathrm{OH})_{4}: \mathrm{NO}_{3}$ ratios averaged ca 2.0 (Table 2).

In March-May 1993, the $\mathrm{Si}(\mathrm{OH})_{4}: \mathrm{NO}_{3}$ ratio at $200 \mathrm{~m}$ along the outer WAP shelf (Fig. 3b) was about 2.0, with lowest values associated with the onshore intrusion of UCDW along Transects 200 and 300 . The $200 \mathrm{~m}$ waters of all the nearshore stations of the WAP had $\mathrm{Si}(\mathrm{OH})_{4}: \mathrm{NO}_{3}$ ratios $>2.6$ while those over the mid-shelf region ranged between 2.0-2.6. Mid-shelf ratios were the lowest, ca 2.3, on Transect 800 (Fig. 3b) where the mixed layer depths (MLD) were shallower and $\mathrm{Si}(\mathrm{OH})_{4}$ concentrations were lower than for other regions (Table 3, no. 6). Mid-shelf ratios of $\mathrm{Si}(\mathrm{OH})_{4}: \mathrm{NO}_{3}$ were highest, ca 2.6, on 



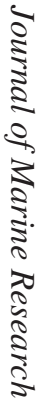

Figure 3. Comparison of the horizontal distribution of the $\mathrm{Si}(\mathrm{OH})_{4}: \mathrm{NO}_{3}$ ratio at a depth of $200 \mathrm{~m}$ for (a) January-February 1993 , (b) March-May 1993, (c) August-September 1993, (d) January-February 1994, and (e) November 1991. Filled circles indicate the distribution of the sampling sites. The progression from darkest to lightest shaded areas represents $\mathrm{Si}(\mathrm{OH})_{4}: \mathrm{NO}_{3}$ ratios of $>2.8,2.4$ to 2.8, 2.0 to 2.4, 1.6 to 2.0 and $<1.6$, respectively. (f) Bathymetry (2000 m, $1000 \mathrm{~m}, 500 \mathrm{~m})$ of the study region. 


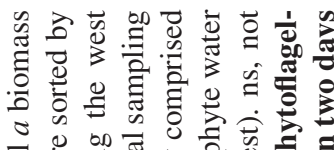

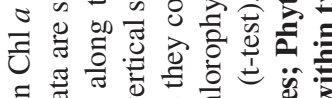

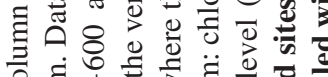

항

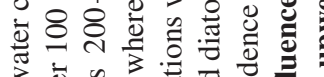

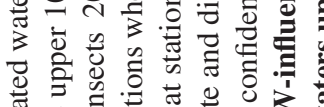

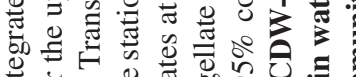

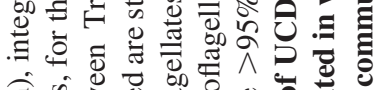

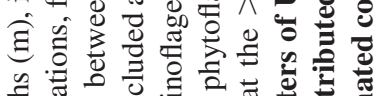

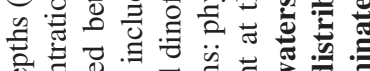



可地

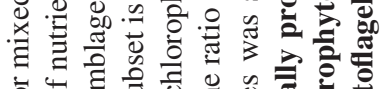



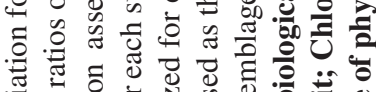



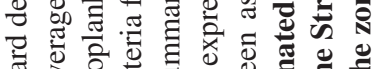

플



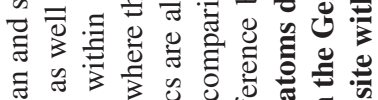

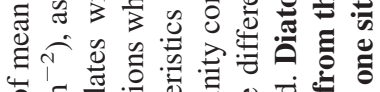

을



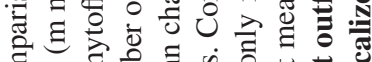



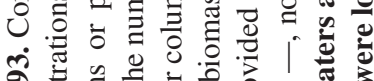

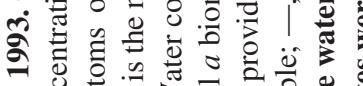

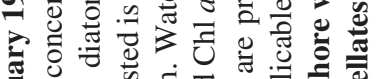

势

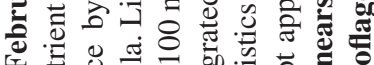

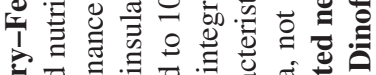



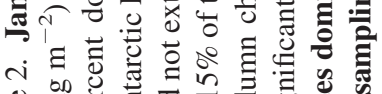

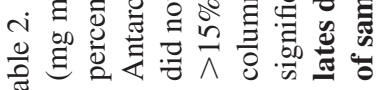

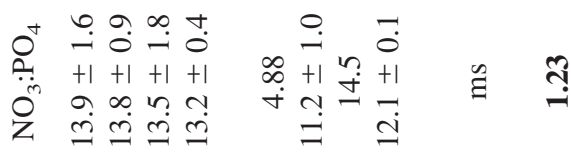

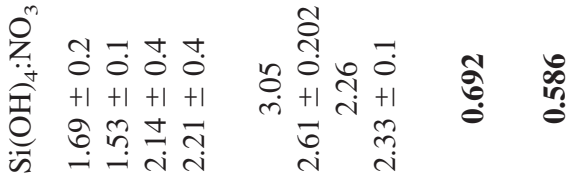

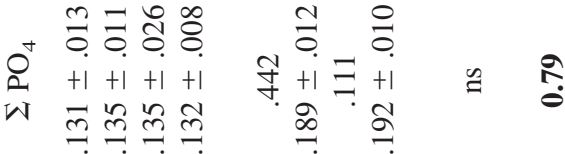

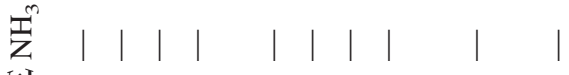

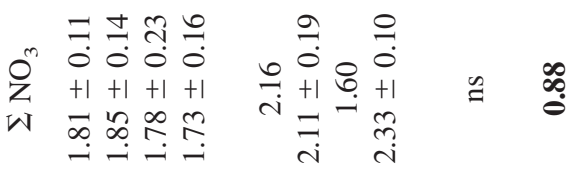

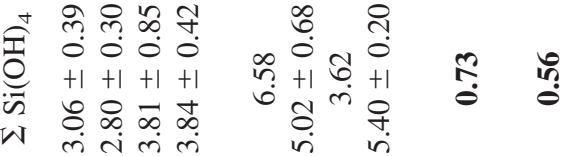

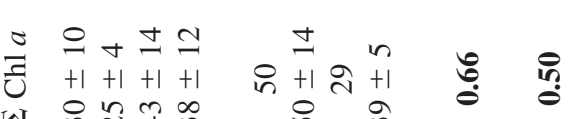

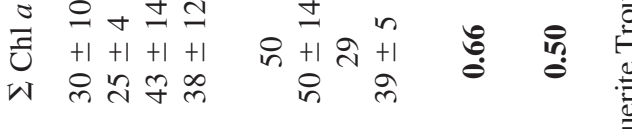

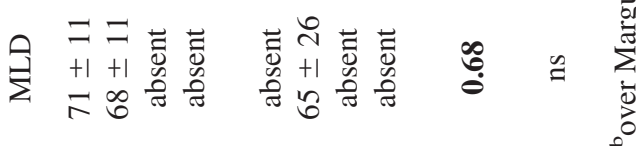

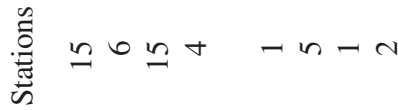

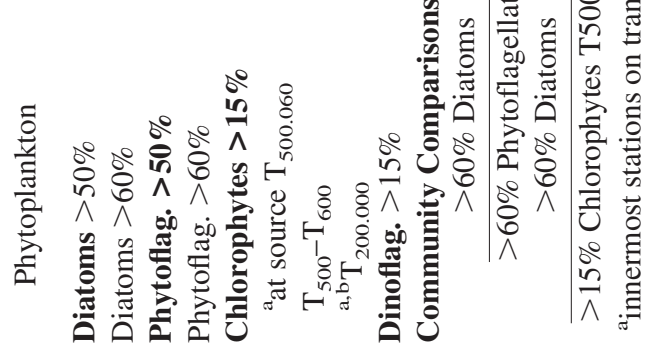


Transects $000-100$ (Fig. 3b). The distribution of $\mathrm{Si}(\mathrm{OH})_{4}: \mathrm{NO}_{3}$ ratios for the upper $100 \mathrm{~m}$ of the water columns generally correlated with those at $200 \mathrm{~m}$.

The $\mathrm{Si}(\mathrm{OH})_{4}: \mathrm{NO}_{3}$ ratio of 3.0 for inner Transect 000 in March-May 1993, where inorganic nutrients and chlorophytes were also abundant, suggested the presence of unmodified UCDW. However, the temperature distribution (Fig. 2b) was colder than unmodified UCDW and the ratio of $\mathrm{NO}_{3}: \mathrm{PO}_{4}$ in these waters (Table 3) was higher than observed for newly intruded UCDW rich in chlorophytes (Table 2). Using chlorophytes $>15 \%$ total chlorophyll $a$ as a marker, this cold water region extended to mid-shelf on Transect 100 where $\mathrm{Si}(\mathrm{OH})_{4}: \mathrm{NO}_{3}$ ratios were ca 2.8 (Table 3).

The $\mathrm{Si}(\mathrm{OH})_{4}: \mathrm{NO}_{3}$ ratio distribution for August-September 1993 (Fig. 3c) resembled that of January 1993 (Fig. 3a). Ratios $<2.0$ occurred along the outer part of all transects, coincident with the UCDW temperature distribution (Fig. 2c). The $\mathrm{Si}(\mathrm{OH})_{4}: \mathrm{NO}_{3}$ ratios for the rest of the region sampled were between 2.0 and 2.5 , with highest values in $1.5^{\circ} \mathrm{C}$ water along the mid-shelf of Transect 500 .

The $\mathrm{Si}(\mathrm{OH})_{4}: \mathrm{NO}_{3}$ pattern observed in January-February 1994 (Fig. 3d) provided a striking contrast to those seen in the 1993 cruises, including the prior summer (Fig. 3a). Values $<2.0$ were observed over most of the region, with lowest values along Transects 500-600. Exceptions were two locales on Transect 400 where the $\mathrm{Si}(\mathrm{OH})_{4}: \mathrm{NO}_{3}$ ratios were $>2.0$. In November 1991, the sea ice-covered UCDW transitional waters had $\mathrm{Si}(\mathrm{OH})_{4}: \mathrm{NO}_{3}$ ratios $<2.0$ at $200 \mathrm{~m}$ (Fig. 3e) while the upper $100 \mathrm{~m}$ had $\mathrm{Si}(\mathrm{OH})_{4}: \mathrm{NO}_{3}$ ratios that averaged $2.0 \pm 0.12$ (Table 6). At $200 \mathrm{~m}$ in the ice-free region and in the upper $100 \mathrm{~m}$ of sampling stations along the 700 transect, $\mathrm{Si}(\mathrm{OH})_{4}: \mathrm{NO}_{3}$ ratios were slightly greater than 2.0 (Fig. 3e, Table 6).

\section{c. Mixed layer characteristics}

The average temperature and salinity of the mixed layer was used to compare the hydrographic structure of the upper water column during the five cruises. The average values were obtained by integrating the temperature and salinity values measured at each hydrographic station to the depth of the maxima in the Brunt-Väisälä frequency, which is a measure of water column stratification. For this analysis, the maximum was assumed to represent the bottom of the mixed layer. The average MLD values were then used to define the portion of a temperature-salinity diagram that characterized the upper water column during each cruise (Fig. 4).

The temperature and salinity of the MLD in January 1993 were characteristic of Antarctic Surface Water (AASW) that forms in the WAP region in the austral summer (Smith et al., 1999). The temperature range reflected seasonal heating that occurs during the spring and summer and the mixed layer salinity range reflected input of freshwater from melting sea ice. The shallowest MLD was ca $65 \mathrm{~m}$ and the deepest was $>100 \mathrm{~m}$ (Table 2).

The March-May period captured the fall transition as the upper water column cooled and sea ice began to form. Average mixed-layer temperature decreased and reached 


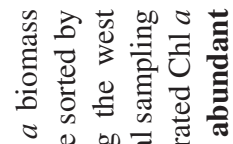

들

ป 䒕 율

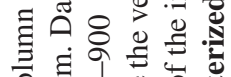
ช

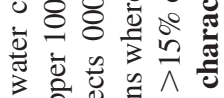

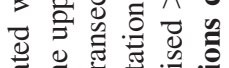

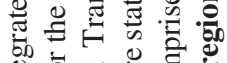

氙

คิ

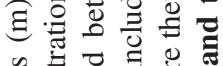

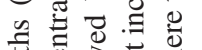

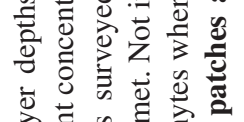

文.

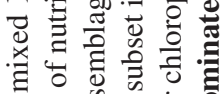

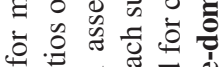

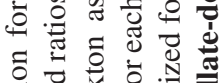

.

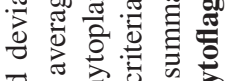

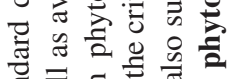

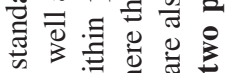

ป

ป

ఏ

Ч

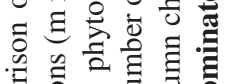

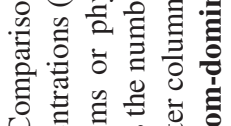



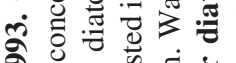



츕요

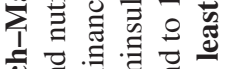

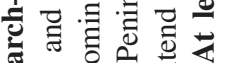



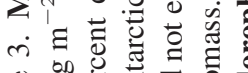

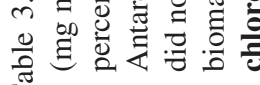

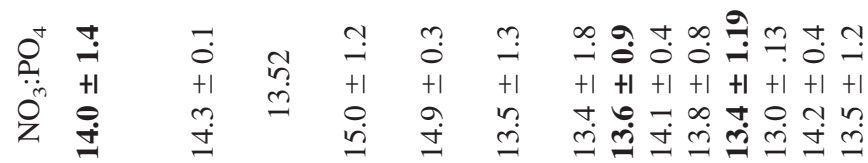

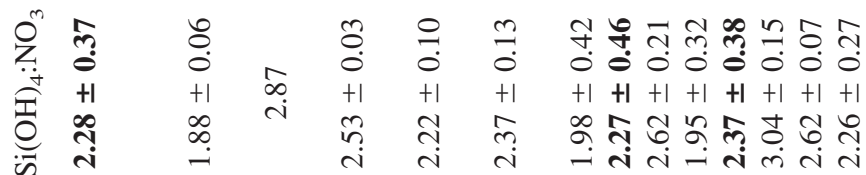

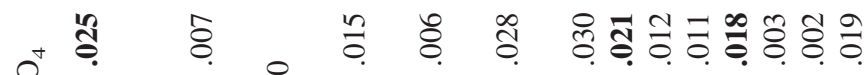

กิ $+i+i \quad+i+i+i+i+i+i+i+i$

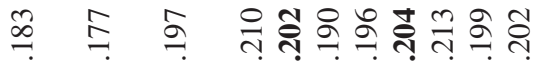

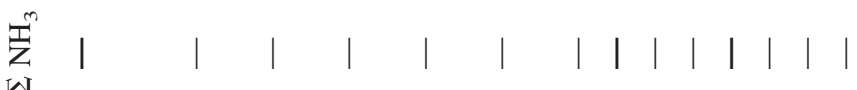





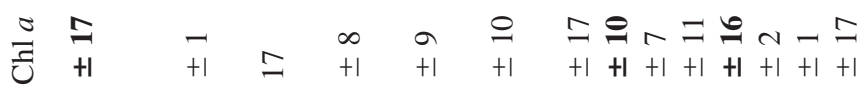

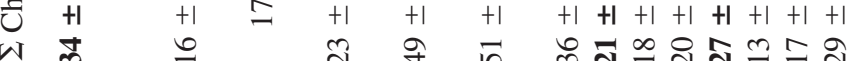

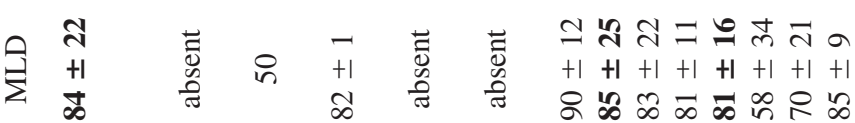

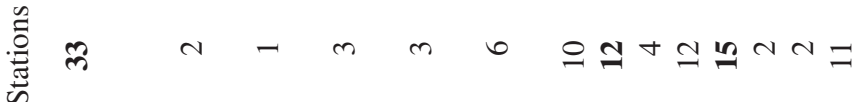

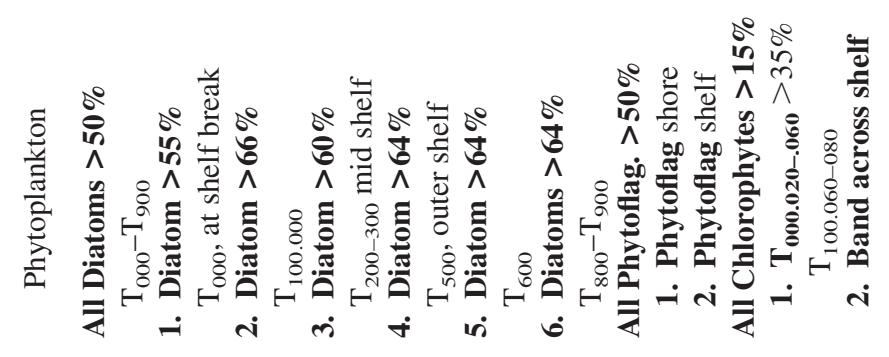






Figure 4. Comparison of the average mixed layer temperature and salinity computed from hydrographic observations made during the 1991, 1993 and 1994 cruises.

freezing at $-1.82^{\circ} \mathrm{C}$. Average salinity of the mixed layer increased in response to brine rejection from freezing surface waters. The MLD increased to about 80 to $>100 \mathrm{~m}$ over the region sampled, except along the outer portions of Transects 100-300 where it was about $67 \mathrm{~m}$ (Table 3). These changes were consistent with increased mixing of the upper water from atmospheric forcing as the fall to winter transition occurs.

By winter (August), the upper water column was composed of only Winter Water (WW), which is characterized by temperatures of $<-1{ }^{\circ} \mathrm{C}$ and salinities of 33.8 to 34.0 (Smith et al., 1999). This water mass replaced the AASW and was formed by the intense cooling that occurs during winter. MLDs were $>100 \mathrm{~m}$ over the entire region (Table 4), which was consistent with intense atmospheric forcing (wind mixing) and convective cooling. The mixed layer in austral spring (November) showed the beginning of warming and the presence of lower salinity waters, as expected from melting sea ice. However, 


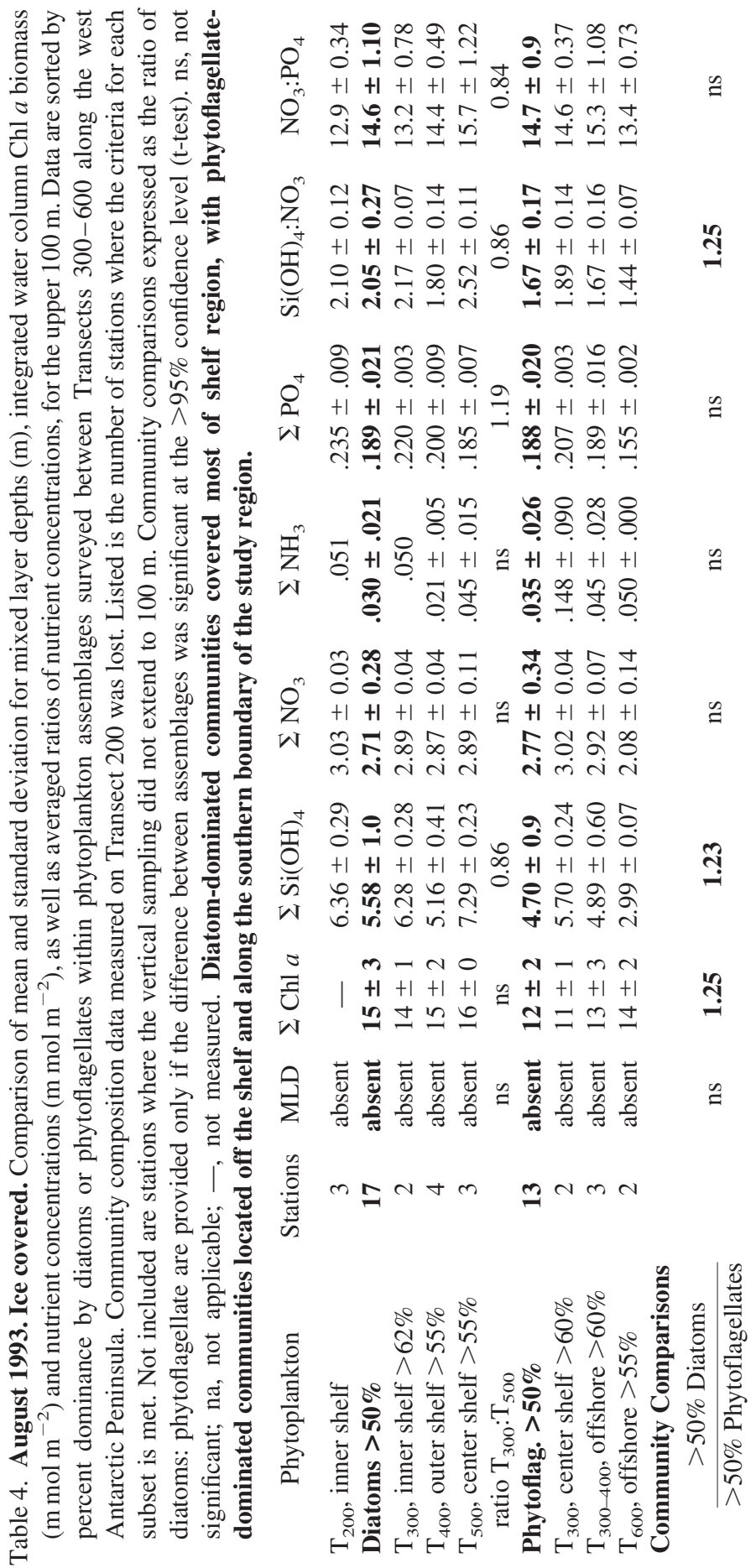


MLDs remained deep (Table 6), suggesting that seasonal heating of the upper water column has not started.

The average temperature and salinity values for the second austral summer (January 1994) showed that mixed-layer structure can vary widely from one summer to the next. In January 1994, the upper water column was colder and saltier than in the previous year, although the two summer cruises occurred at approximately the same time (Table 1). The colder temperatures and smaller range of temperature values suggests that seasonal warming was delayed in 1994 and the higher salinity implies less freshwater input. Observations show that sea ice retreat occurred later in the austral spring and summer of 1994 than in 1993 (Moline and Prézelin, 1996a; Lascara et al., 1999), which is consistent with the patterns seen in the average thermohaline properties of the mixed layer. In addition, MLDs were shallow (Table 5), suggesting that seasonal heating had started, but that the water had not been exposed to strong atmospheric forcing.

\section{d. Percent diatom distributions in the upper $100 \mathrm{~m}$}

During the austral summer of 1993, diatom dominance was highest $(>60 \%)$ in the upper $100 \mathrm{~m}$ along the outer and mid-shelf of Transect 300 (Fig. 5a), where UCDW was moving onto the shelf (Fig. 2b) and where $\mathrm{Si}(\mathrm{OH})_{4}: \mathrm{NO}_{3}$ ratios at $200 \mathrm{~m}$ were $<1.6$ (Fig. 3a). Regions with $>50 \%$ diatoms were located on the outer part of all the other transects (Fig. 5a), a distribution that closely correlated with the distribution of UCDW on the WAP shelf (Fig. 2a) and with $\mathrm{Si}(\mathrm{OH})_{4}: \mathrm{NO}_{3}$ ratios of 1.6-1.8 (Fig. 3a). Just shoreward of these diatom-dominated waters, there was a band of modified UCDW water with 40-50\% diatoms (Fig. 5a) and $\mathrm{Si}(\mathrm{OH})_{4}: \mathrm{NO}_{3}$ ratios at $200 \mathrm{~m}$ of $1.8-2.0$. Areas with just $30-40 \%$ diatoms were confined to the east of Transect 400 and associated with modified UCDW with $\mathrm{Si}(\mathrm{OH})_{4}: \mathrm{NO}_{3}$ ratios at $200 \mathrm{~m}$ of 2.0-2.3. On inner parts of Transects 500-600 (Fig. 5), diatoms were $<25 \%$ of assemblages, $200 \mathrm{~m}$ temperature was $>1.4^{\circ} \mathrm{C}$ and $\mathrm{Si}(\mathrm{OH})_{4}: \mathrm{NO}_{3}$ ratios were $>2.6$.

In January 1993, the integrated chlorophyll $a$ in the upper $100 \mathrm{~m}$ in diatom-dominated regions was 30\% and 50\% less, respectively, than for phytoflagellate-dominated and chlorophyte-containing regions (Table 2). The integrated $\mathrm{Si}(\mathrm{OH})_{4}$ concentration was lowest in the diatom-dominated regions. Removal of $\mathrm{Si}(\mathrm{OH})_{4}$ by diatoms was reflected in $30-40 \%$ lower $\mathrm{Si}(\mathrm{OH})_{4}: \mathrm{NO}_{3}$ ratios than for non-diatom dominated regions. Integrated $\mathrm{NO}_{3}$ and phosphate $\left(\mathrm{PO}_{4}\right)$ concentrations were similar in diatom-dominated and phytoflagellate-dominated regions and about $20 \%$ higher in regions with abundant chlorophytes (Table 2).

In the austral fall of 1993, integrated chlorophyll $a$ for all diatom-dominated regions was greater than those for areas dominated by phytoflagellates and chlorophytes and for diatom-dominated areas sampled during the austral summer two months earlier (Table 3). Integrated nitrate concentrations in the upper $100 \mathrm{~m}$ were higher in March-May than in January 1993 (Tables 2, 3). By comparison, $\mathrm{Si}(\mathrm{OH})_{4}$ and $\mathrm{Si}(\mathrm{OH})_{4}: \mathrm{NO}_{3}$ ratios were lower in diatom-dominated regions and $\mathrm{NO}_{3}: \mathrm{PO}_{4}$ ratios everywhere were generally higher than 

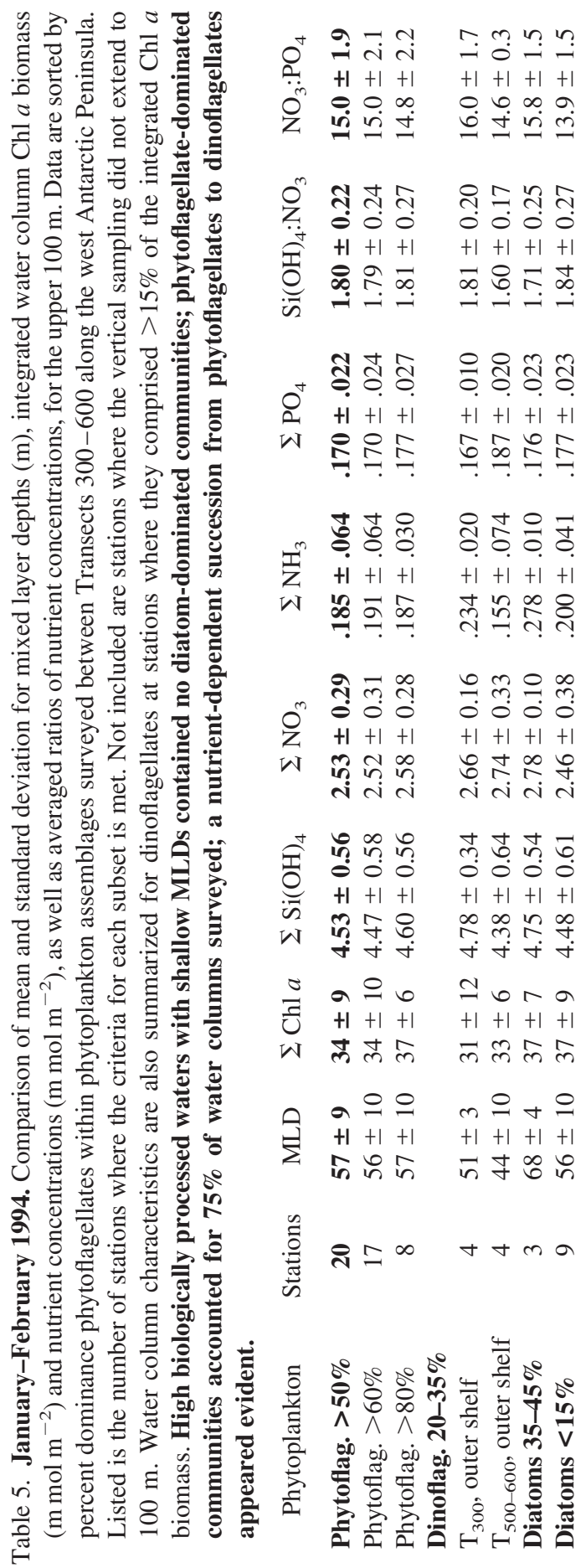
Percent Diatoms within Phytoplankton Communities, for the upper $100 \mathrm{~m}$
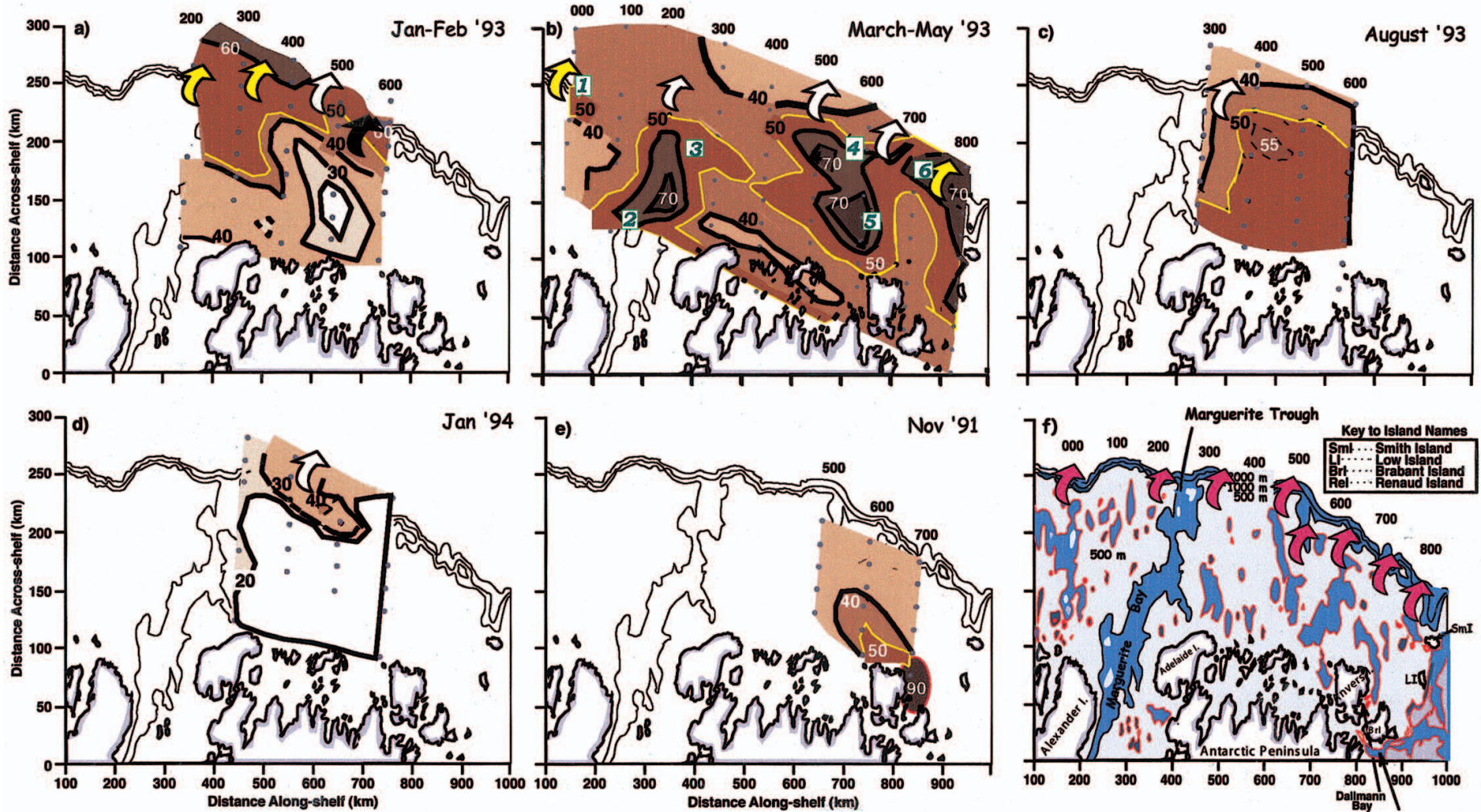

Figure 5. Comparison of the horizontal distribution of the percent diatoms within phytoplankton assemblages that were vertically integrated to $100 \mathrm{~m}$ for (a) January-February 1993, (b) March-May 1993, (c) August-September 1993, (d) January-February 1994, and (e) November 1991. Filled circles indicate the distribution of the sampling sites. The progression from darkest to lightest shaded areas indicates diatom percent contributions of $>70 \%, 60$ to $70 \%, 50$ to $60 \%, 30-50 \%$ and $<30 \%$ respectively. (f) Bathymetry (2000 m, $1000 \mathrm{~m}, 500 \mathrm{~m}$ ) of the study region. 
those observed in the austral summer. In March-May 1993, several groupings of diatomdominated assemblages were identifiable along $900 \mathrm{~km}$ of the WAP (Fig. 5b). At the center of each grouping, diatoms accounted for $>70 \%$ of the water column chlorophyll $a$. One grouping was found along inner Transect 200, in proximity to Marguerite Trough near Adelaide Island, and overlaid modified UCDW water that had relatively high $\mathrm{Si}(\mathrm{OH})_{4}: \mathrm{NO}_{3}$ ratios of 2.6-2.8 (Table 3). There were indications of another patch intruding from the south on to the outer shelf of Transect 000. Two additional diatom patches encompassed most of the shelf between Transects 500-600 that coincided with modified UCDW $\left(1.3-1.4^{\circ} \mathrm{C}\right)$; with $\mathrm{Si}(\mathrm{OH})_{4}: \mathrm{NO}_{3}$ ratios of $2.1-2.3$ on outer Transect 500 and $2.4-2.5$ on inner Transect 600 . The chlorophyll $a$ of these patches was about three times as high as concentrations observed in patches on Transects 000-200 (Table 3). A fifth diatom patch was detected along the continental shelf break between Transects 700-800 and appeared to extend across the shelf to the Gerlache Strait (Fig. 5b). Diatom dominance was evident all along Transect 800 and coincided with the lowest $\mathrm{Si}(\mathrm{OH})_{4}: \mathrm{NO}_{3}$ ratios observed $(<1.9)$. The mid- to inshore shelf portions of Transect 800 were covered with deep waters $<1.2^{\circ} \mathrm{C}$ and $\mathrm{Si}(\mathrm{OH})_{4}: \mathrm{NO}_{3}$ ratios at $200 \mathrm{~m}$ were 2.2-2.5. The coldest deep water, with $\mathrm{Si}(\mathrm{OH})_{4}: \mathrm{NO}_{3}$ ratios $>2.6$ and no diatom-dominated communities, was found at inner shelf of Transect 800 , among the many islands present in this region.

By late winter, in August 1993, diatom-dominated communities were uniformly spread over most of the WAP continental shelf between Transects 400-600 and innermost Transect 300 (Fig. 5c). The highest percentage of diatoms (approaching 60\%) was located over modified UCDW near the outer edge Transect 400 (Fig. 2c), with $\mathrm{Si}(\mathrm{OH})_{4}: \mathrm{NO}_{3}$ ratios of 2.2-1.8 (Fig. 3c), and the innermost stations of Transect 300 (Fig. 2c) near Marguerite Trough, with $\mathrm{Si}(\mathrm{OH})_{4}: \mathrm{NO}_{3}$ ratios of 2.2-2.0 (Fig. 3c). The integrated chlorophyll $a$ in the upper $100 \mathrm{~m}$ in August 1993 was low in all areas (Table 4). Integrated silicate concentrations were ca $25 \%$ higher in diatom-dominated regions, while concentrations of nitrate and phosphate were similar for all regions. Thus, $\mathrm{Si}(\mathrm{OH})_{4}: \mathrm{NO}_{3}$ ratios were elevated in diatom-dominated regions in late winter while $\mathrm{NO}_{3}: \mathrm{PO}_{4}$ ratios were similar for diatom and phytoflagellate dominated areas (Table 4).

By austral summer of January 1994, there were no diatom-dominated communities in the study region (Fig. 5d). Chlorophyll $a$ in the upper $100 \mathrm{~m}$ was dominated by phytoflagellates. Communities with $>40 \%$ diatoms were located at the outer Transect 500, coincident with UCDW and $\mathrm{Si}(\mathrm{OH})_{4}: \mathrm{NO}_{3}$ ratios $<1.8$. The vertical distribution of phytoplankton measured in January 1994 (not shown) indicated that diatom-dominated communities were located at depths $>100 \mathrm{~m}$ at the inner station of Transect $500(>60 \%$ diatoms) and $>80 \mathrm{~m}$ at mid-shelf on Transect 600 (100\% diatoms) with ammonium $\left(\mathrm{NH}_{3}\right)$ significantly higher than elsewhere (Table 5). High ammonium may be indicative of a post bloom sedimentation or lateral advection of diatom particles from an earlier UCDW event. It is also indicative of the additional inorganic nitrogen load possible within a recycling diatom 'seed' community.

During the austral spring cruise in November 1991 (Fig. 5e), the marginal ice zone 
(MIZ) extended to the outer continental shelf between Transects 500-700. Diatoms were not prevalent in the MIZ but abundant in open waters of Dallmann Bay where a subsurface diatom bloom was observed at a MLD of about $67 \mathrm{~m}$ (Table 6). The diatom bloom was physically isolated from the modified UCDW evident in the outer shelf regions (Fig. 2e).

\section{e. Phytoplankton community composition}

In January 1993, diatoms dominated the outer shelf waters of Transects 200-600 and extended into the mid-shelf of Transects 200-300 (Fig. 6a). Diatoms also dominated communities below the fresher water lens (FWL) that formed on the inner part of Transect 400 from glacial melt. In the FWL, dinoflagellates were prevalent. In diatom-dominated communities, phytoflagellates were the second most abundant phytoplankton group and visa versa. Phytoflagellate-dominated communities extended from inner Transects 200300 through the mid-shelf of Transect 400 and throughout inner and mid-shelf regions of Transect 600. Phytoflagellates did not dominate similar regions of Transect 500 due to abundant chlorophytes. In January 1993, bands of concentrated chlorophytes were located coincident with modified UCDW at the leading edge of UCDW, e.g. from inner Transect 200 to mid-shelf Transect 400 and inshore of a region of UCDW upwelling on Transect 500 (Fig. 6a). Other conditions also lead to abundant chlorophytes. In the cold waters of Marguerite Bay (Fig. 5f), chlorophytes were ca 30\% of water column chlorophyll $a$.

In March-May of 1993 (Fig. 6b), diatom-dominated communities covered most of the WAP shelf and would have dominated several adjacent sites, except for the high abundance of chlorophytes. Several groupings of diatom-dominated communities were present (Fig. 5b), some separated from each other by phytoflagellate-dominated communities located along the inner and outer portions of most transects (Fig. 6b). Each diatom group seemed to be associated with different UCDW intrusion events. There were confluences of more than one diatom-dominated group (Fig. 5b) where distinctions were evident only in comparisons of hydrographic (Fig. 2), nutrient (Table 3) and physiological parameters (see below). Chlorophytes were abundant in what appeared to be an acrossshelf band of patches that were associated with modified UCDW and UCDW intrusions.

Chlorophytes were also abundant in areas not apparently influenced by UCDW. On the inner shelf of Transect 000 in austral fall 1993, chlorophytes accounted $>35 \%$ (Fig. 5b) of chlorophyll $a$ in an area where the $\mathrm{Si}(\mathrm{OH})_{4}: \mathrm{NO}_{3}$ ratios were $>3.0$ and $\mathrm{NO}_{3}: \mathrm{PO}_{4}$ ratios were ca. 13 (Table 3). The MLD was ca $60 \mathrm{~m}$ and yet there was no indication of UCDW at $200 \mathrm{~m}$ where water temperature was $1.2^{\circ} \mathrm{C}$. Adjacent diatom-dominated communities, also with shallow MLDs, were almost as enriched in nutrients and contained somewhat higher levels of chlorophyll $a$, but no chlorophytes.

In March-May 1993, diatom groupings 2 and 3 (Figs. 5b and 6b) appear to have resulted from separate UCDW events, most likely two intrusions that moved across the shelf via Marguerite Trough. The $\mathrm{Si}(\mathrm{OH})_{4}: \mathrm{NO}_{3}$ ratios of ca. 2.4-2.5 and $\mathrm{NO}_{3}: \mathrm{PO}_{4}$ ratios approaching 15 (Table 3 ) indicate that biological processing of the water has occurred. The lower $\mathrm{Si}(\mathrm{OH})_{4}: \mathrm{NO}_{3}$ ratios of 2.2 , and higher chlorophyll $a$ concentrations suggest that diatom 


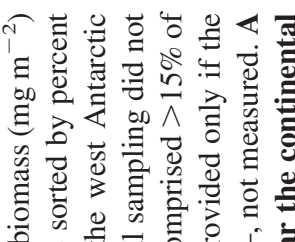

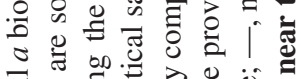
芜



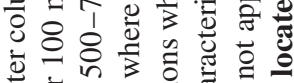



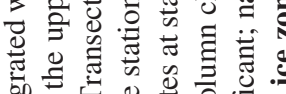
窇

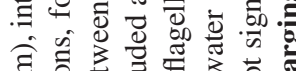
हิ

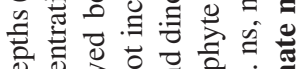

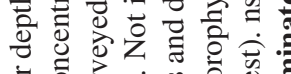

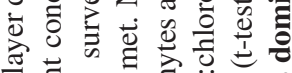

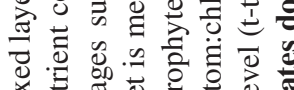
. t) .0.

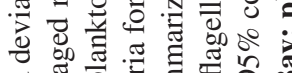
문 $\frac{\pi}{0}$

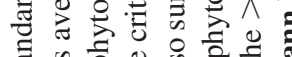

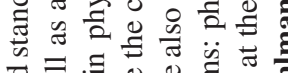



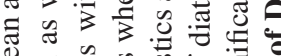

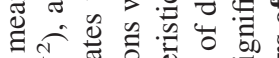
苍

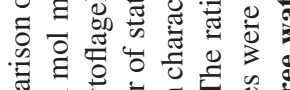

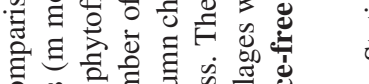



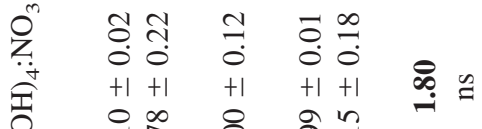



0

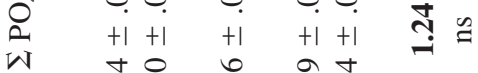
W 워 ๖

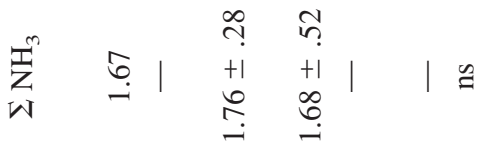





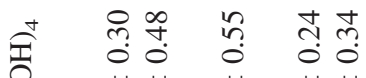

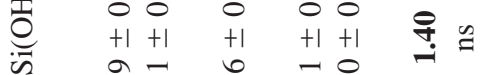

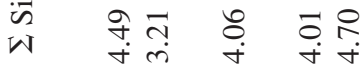

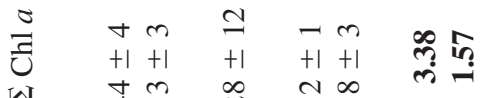
W $₫ \stackrel{\infty}{N \infty}$

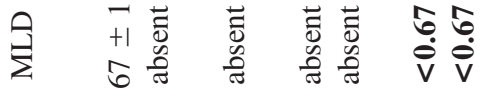

总 $N d \bigcirc N$ ن

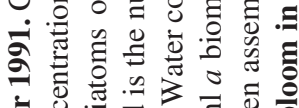

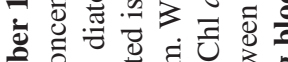


乙.

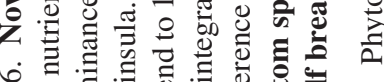

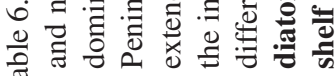

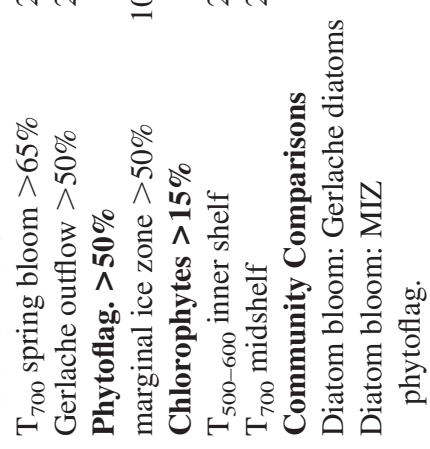


Phytoplankton Community Composition, integrated average for the Upper $100 \mathrm{~m}$
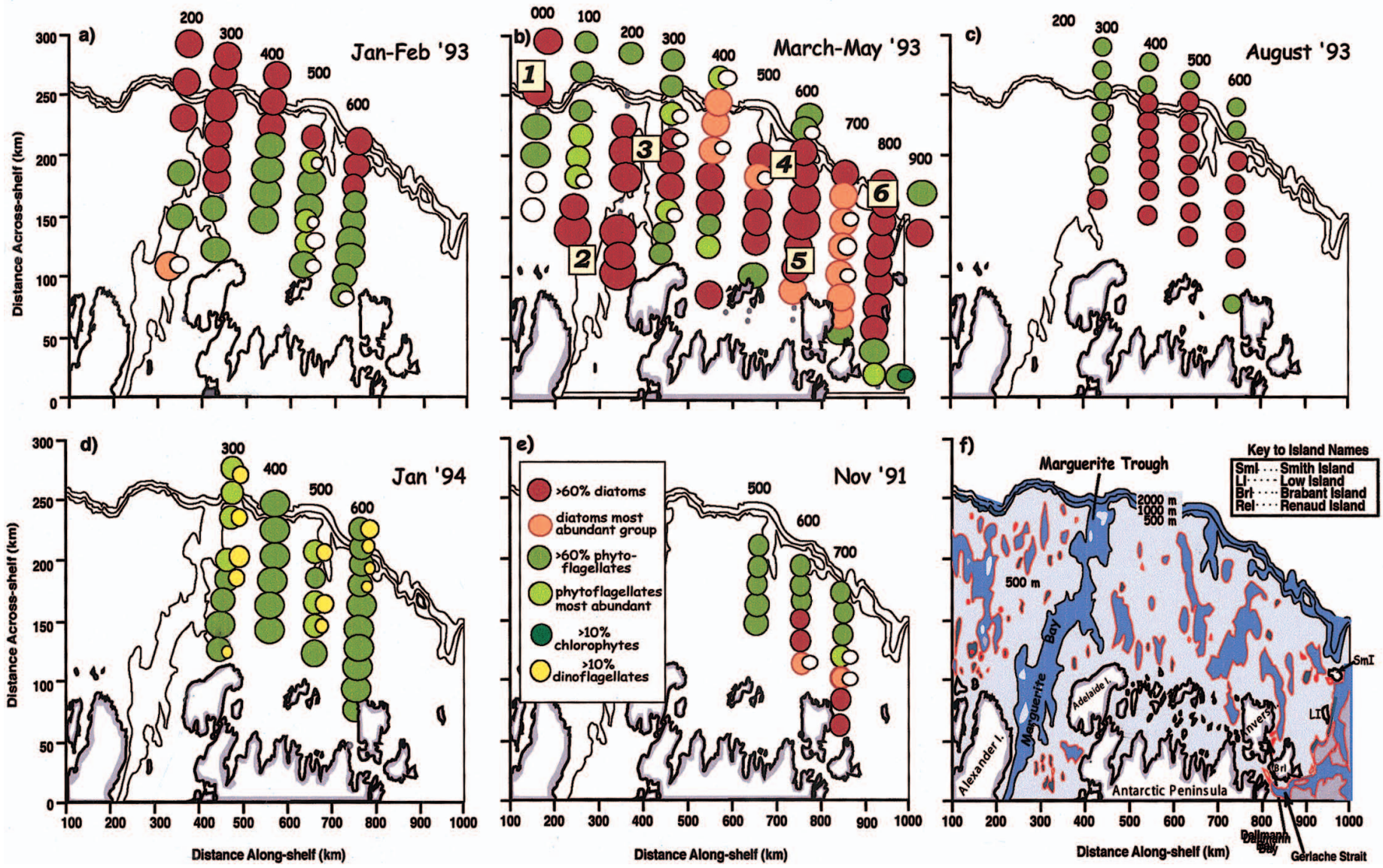
group 4 on the outer shelf of Transect 500 resulted from a later stage UCDW intrusion event. Diatom group 5, inshore on Transect 500, had hydrographic, nutrient, and phytoplankton community characteristics similar to group 4 , but different photosynthetic physiologies that suggest a younger 'stage' (see below). Diatom group 6 resulted from a large UCDW event that influenced the entire across-shelf region along Transect 800 as well as the outer shelf portions of Transects 700-900 (Fig. 6b). The variability in the nutrient concentrations associated with diatom group 6 is sufficient to warrant further subdivision or to regard this as a large UCDW event in which the inshore waters were at a later stage ('aged') than outer shelf waters. Diatom groups 5 and 6 were separated from each other by a band of chlorophytes on Transect 700. Inshore, these diatom-dominated regions were constrained by phytoflagellate-dominated communities in the colder waters of the Gerlache Strait outflow (Fig. 2), which was as enriched in inorganic macronutrients as those of diatomdominated waters (Table 3). Thus, differences in the structure of these phytoplankton communities suggested that UCDW provided necessary diatom growth requirements and that the Gerlache Strait outflow did not support the development of diatom communities.

In the austral spring of August-September 1993, when much of the shelf was covered by sea ice, diatoms dominated communities on the shelf over most of Transects 400-600 (Fig. 6c). Phytoflagellate-dominated communities were found in the southern part of the study region, where the sea ice was thicker along Transect 300, along the entire outer shelf and in the outflow of the Gerlache Strait. Other phytoplankton taxa were largely absent. On average, $\mathrm{Si}(\mathrm{OH})_{4}: \mathrm{NO}_{3}$ ratios and chlorophyll $a$ concentrations were ca $25 \%$ lower in phytoflagellate communities compared with diatom communities (Table 3). Silicate concentrations of outer shelf phytoflagellate communities were ca half those of onshore phytoflagellate communities. While appearing rather homogeneous, diatoms on Transect 400 were in waters where $\mathrm{Si}(\mathrm{OH})_{4}: \mathrm{NO}_{3}$ ratios at $200 \mathrm{~m}$ were $<2.0$ compared to values ca 2.4 on Transects 500-600. The UCDW intrusion on Transect 300 was associated with reduced prevalence of diatoms (Fig. 5c) but decreased $\mathrm{Si}(\mathrm{OH})_{4}: \mathrm{NO}_{3}$ ratios, indicating that this may be a relatively new event.

In the following austral summer of January 1994, phytoflagellates dominated the phytoplankton community over the entire study region, often in association with increased

Figure 6. Phytoplankton community composition, integrated average for the upper $100 \mathrm{~m}$ for (a) January-February 1993, (b) March-May 1993, (c) August-September 1993, (d) JanuaryFebruary 1994, and (e) November 1991 . Water column communities comprised of $>60 \%$ diatoms are represented by dark brown circles and those comprised $>60 \%$ phytoflagellates are represented by open green circles. Where neither diatoms nor phytoflagellates are dominant due to the relative abundance of lesser groups of phytoplankton, the circles are of a lighter hue. Larger diatom and phytoflagellate circle size vary directly with chlorophyll $a$ biomass. The relative abundance of chlorophytes (between 5 and 25\%) and dinoflagellates (between 5 and 35\%) are represented by the open and yellow circles, respectively. Circle size varies in relative proportion to their dominance.

(f) Bathymetry $(2000 \mathrm{~m}, 1000 \mathrm{~m}, 500 \mathrm{~m})$ of the study region. 
abundances of dinoflagellates in stratified near-surface waters (Fig. 6d). No diatomdominated communities were evident. No significant concentrations of chlorophytes were present (Fig. 6d). In contrast to the nutrient-rich conditions observed in January 1993, water column nutrients were severely depleted in January 1994, which provides further evidence that UCDW intrusions are not seasonal and that intervals between UCDW events can, at times, be long enough for significant phytoplankton community succession to occur over large portions of the WAP continental shelf.

The only other comparison between ice-covered sea versus non- ice-covered sea regions occurred in the austral spring of 1991, when sea ice covered Transects 500-600 and the inner Transect 700 (Dallmann Bay) was largely ice free. The phytoplankton communities in the MIZ (Fig. 5e) were heavily concentrated in near-surface waters and completely dominated by phytoflagellates, especially Phaeocystis spp. A major diatom bloom dominated the subsurface waters of the ice-free regions of Dallmann Bay (Fig. 5d). There was a small intrusion of UCDW at the outer shelf of Transect 700, although it is not thought to be the cause of the diatom bloom. Likewise, the diatoms in Gerlache Strait were in nutrient-poorer water than those associated with the bloom in Dallmann Bay (Table 6). Chlorophytes were found only at depth on Transects 500-600.

\section{f. Phytoplankton community succession and nutrient ratios}

The distributions of diatom dominance (Fig. 5) and the phytoplankton community composition (Fig. 6) obtained from the five cruises give the impression of succession of the phytoplankton communities. The diatom-dominated communities tend to be associated with regions where UCDW has moved onto the WAP shelf and other taxa dominate outside these areas. A change in dominance may also arise because of sudden advective changes or slower progressive changes in nutrient concentration or changes in nutrient ratios (Moline and Prézelin, 1996a). For example, in the intervals between UCDW intrusion events, when nutrients were not mixed or upwelled into the upper water column, phytoflagellates became increasingly dominant as the surface waters 'aged' and nutrients were depleted. Thus, changes in phytoplankton community composition observed during the different cruises were examined within the context of the $\mathrm{Si}(\mathrm{OH})_{4}: \mathrm{NO}_{3}$ ratio and $\mathrm{NO}_{3}: \mathrm{PO}_{4}$ ratios (Fig. 7). These ratios are indicative of the water mass present and provide an approach for identifying nutritional regimes that favor certain phytoplankton groups and discourage others.

The March-May 1993 phytoplankton community assemblages were highly variable (cf. Figs. 5b, 6b), creating a mosaic of discrete communities associated with the largest range of $\mathrm{Si}(\mathrm{OH})_{4}: \mathrm{NO}_{3}$ ratios measured during all five cruises (Fig. 7b). Diatom communities associated with $\mathrm{Si}(\mathrm{OH})_{4}: \mathrm{NO}_{3}$ ratios of 3.0-3.5 were in newly intruded UCDW and were in the early phases of growth, e.g. communities associated with Marguerite Trough. Those associated with low $\mathrm{Si}(\mathrm{OH})_{4}: \mathrm{NO}_{3}$ ratios $(1.8-2.0)$ were actively growing, e.g. the northern part of the study region near Transect 800 .

In August 1993, the range of $\mathrm{Si}(\mathrm{OH})_{4}: \mathrm{NO}_{3}$ and $\mathrm{NO}_{3}: \mathrm{PO}_{4}$ ratios was smaller and the 

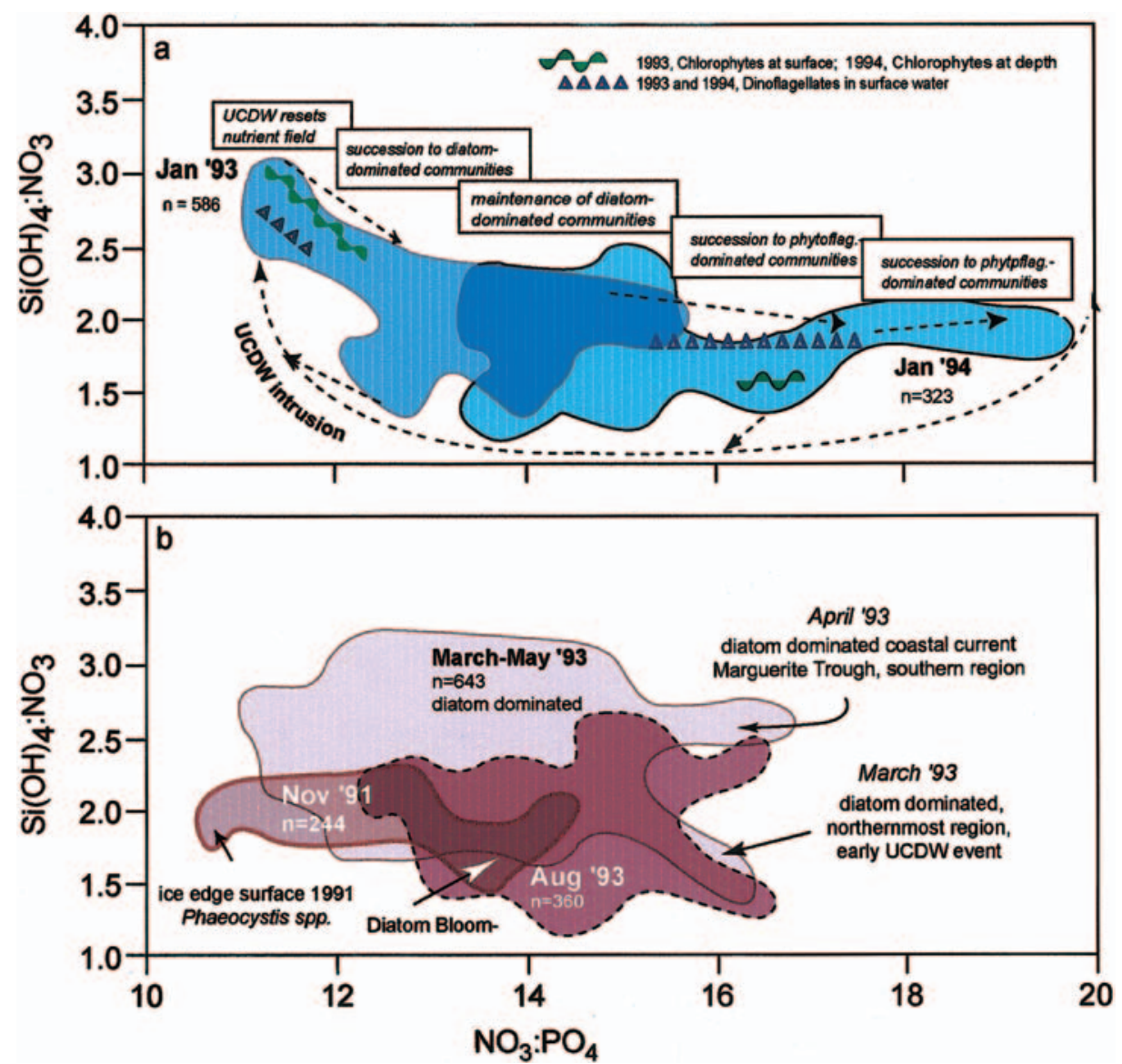

Figure 7. Comparison of the distribution of $\mathrm{Si}(\mathrm{OH})_{4}: \mathrm{NO}_{3}$ versus $\mathrm{NO}_{3}: \mathrm{PO}_{4}$ ratios for each depth for which nutrient samples were collected during (a) the austral summers of January 1993 and 1994 and (b) March 1993, August 1993, and November 1991. The dashed arrows indicate the direction of changes in the two nutrient ratios that occur as phytoplankton communities progress toward diatom-dominance (January 1993) and, in the absence of inputs of nutrients via UCDW intrusions, the further progression to phytoflagellate-dominated communities where dinoflagellates became significant components in late stage succession. The data clusters associated with particular regions of the shelf during various cruises are indicated by the solid arrows. The presence and duration of chlorophytes (squiggle line, 1993) and dinoflagellates (triangles) within the boundary of samples are indicated.

transition from high to low $\mathrm{Si}(\mathrm{OH})_{4}: \mathrm{NO}_{3}$ ratios was associated with the change from diatom to phytoflagellate-dominated communities. In austral spring (November 1991), the lowest $\mathrm{NO}_{3}: \mathrm{PO}_{4}$ ratios of all cruises were observed with a bloom of Phaeocystis spp. in the MIZ. The large diatom bloom observed in open water was associated with low $\mathrm{Si}(\mathrm{OH})_{4}$ : $\mathrm{NO}_{3}$ ratios. 

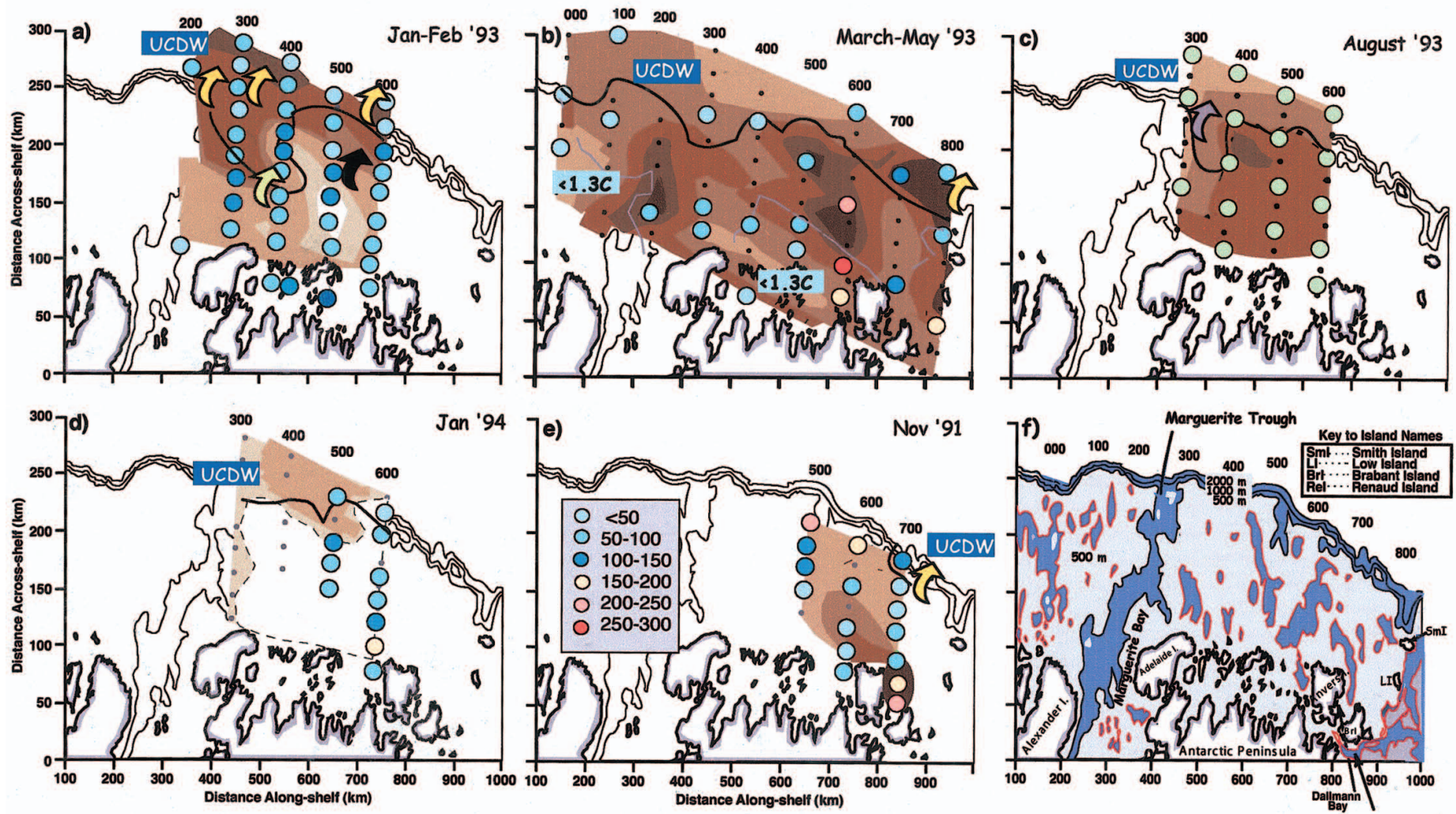

Figure 8. 
Comparison of nutrient ratios from the two summers (Fig. 7a) shows differences that result from dominance by diatoms versus phytoflagellates. Diatoms became dominant when UCDW intrusions replenished macronutrients and perhaps necessary trace metals. Diatoms lower the initially high $\mathrm{Si}(\mathrm{OH})_{4}: \mathrm{NO}_{3}$ ratios $(>3.0)$ by preferential uptake of abundant $\mathrm{Si}(\mathrm{OH})_{4}$. At intermediate $\mathrm{Si}(\mathrm{OH})_{4}: \mathrm{NO}_{3}$ ratios (2.5 to 2.0) and $\mathrm{NO}_{3}: \mathrm{PO}_{4}$ ratios, diatoms and phytoflagellates dominance overlap with phytoflagellates becoming dominant at higher $\mathrm{NO}_{3}: \mathrm{PO}_{4}$ ratios. Dominance by phytoflagellates occurred when $\mathrm{NO}_{3}: \mathrm{PO}_{4}$ ratios were high and $\mathrm{Si}(\mathrm{OH})_{4}: \mathrm{NO}_{3}$ ratios were $<2.5$.

\section{g. Primary production and growth physiology}

Comparisons of the distributions of potential volumetric primary production, integrated chlorophyll $a$, and Chl-specific rates of primary production, with each overlaid on a background showing the percent diatom distribution, are provided in Figures 8-10, respectively. A comparison of the photosynthetic characteristics of diatom-dominated and phytoflagellate-dominated communities for each cruise is provided in Table 7. Average daytime rates of volumetric production should be considered a zero-order estimate, as temporal corrections for in situ diurnal periodicity of photosynthesis were simplified with the use of a standard curve. Potential-specific rates of primary production $\left(\mathrm{P}_{\mathrm{MAX}} / \mathrm{Chl} a\right)$ are considered a proxy for growth, assuming light-saturated conditions in the upper $60 \mathrm{~m}$ of the water column. Particulate organic carbon (POC) concentrations were used in estimates of carbon turnover times.

In January 1993, volumetric production was greatest in the UCDW transition waters between diatom-dominated and phytoflagellate-dominant communities, evident as an across-shelf band of production from near-shore on Transect 300 to off shelf on Transect 600 (Fig. 8a). Compared to phytoflagellate-dominated water columns on a regional scale, diatom-dominated water columns appeared $40 \%$ less productive (Fig. 8a), had 50\% less Chl $a$ (Fig. 9a), 20\% less POC and the same abundance of particulate organic nitrogen (PON) (data not shown). Diatom communities had a higher light requirement for lightsaturated photosynthesis $\left(I_{k}\right)$ and lower relative photosynthetic quantum efficiency (alpha/ $\mathrm{Chl})$ than phytoflagellate communities. The carbon-to-nitrogen (C:N,wt:wt) ratios averaged $5.5 \pm 0.5(n=14)$ for diatom-dominated water columns and $6.4 \pm 1.6(n=11)$ for

Figure 8. Comparison of volumetric primary production integrated over the upper $60 \mathrm{~m}$ (circles), relative to the distribution of diatom-dominated communities (shown as background, see Fig. 5) and UCDW distribution (black contour line) for (a) January-February 1993, (b) March-May 1993, (c) August-September 1993, (d) January-February 1994, and (e) November 1991. Grey contour line is The boundary of waters $<1.3^{\circ} \mathrm{C}$ is indicated by the gray line. The locations of UCDW intrusions during three of the five cruises are indicated by the yellow arrows; a site of wind-driven upwelling observed in January 1993 is indicated by the black arrow; a site with an intrusion but with no observed upwelling or upward mixing of Upper Circumpolar Deep Water is indicated by the gray arrow. 
Table 7. Average photosynthetic characteristics of diatom-dominated communities expressed as a ratio of those determined to phytoflagellate-dominated communities during four cruises on the continental shelf of the west Antarctic Peninsula. January 1994 data are not included as there were no diatom-dominated communities in the sampling region at that time. Values are based upon integrated or integrated averages of biomass and productivity, respectively, for the upper $60 \mathrm{~m}$ for all sampling stations given in Figure 7.

\begin{tabular}{|c|c|c|c|c|c|}
\hline Cruise & $\begin{array}{l}\text { Diatom: } \\
\text { Phytofl. Chl } a \\
\text { (biomass) }\end{array}$ & $\begin{array}{c}\text { Diatom: } \\
\text { Phytofl. Midday } \\
\text { Pmax/Vol } \\
\text { (potential } \\
\text { production) }\end{array}$ & $\begin{array}{l}\text { Diatom: } \\
\text { Phytofl. } \\
\text { Pmax/Chl } a \\
\text { (growth } \\
\text { potential) }\end{array}$ & $\begin{array}{l}\text { Diatom: } \\
\text { Phytofl. } I_{k} \\
\text { (light } \\
\text { requirement) }\end{array}$ & $\begin{array}{l}\text { Diatom: } \\
\text { Phytofl. } \\
\text { Alpha/Chl } a \\
\text { (rel. quantum } \\
\text { efficiency) }\end{array}$ \\
\hline January 1993 & 0.53 & 0.63 & $\begin{array}{c}\text { No significant } \\
\text { difference }\end{array}$ & 1.45 & 0.68 \\
\hline March $1993 * *$ & 2.36 & 2.74 & 1.26 & 1.60 & 0.83 \\
\hline August 1993 & $\begin{array}{c}\text { No significant } \\
\text { difference }\end{array}$ & 1.43 & 1.36 & 0.71 & 1.9 \\
\hline November 1991* & 1.57 & 1.42 & $\begin{array}{c}\text { No significant } \\
\text { difference }\end{array}$ & $\begin{array}{c}\text { No significant } \\
\text { difference }\end{array}$ & 1.37 \\
\hline
\end{tabular}

phytoflagellate-dominated water columns. The POC-based turnover times were estimated to be almost three times as fast for diatom-dominated communities as for phytoflagellatedominated communities e.g. $1.71 \pm 0.88$ days and $4.87 \pm 1.02$ days, respectively.

In January 1993, the Chl-specific assimilation rates were $>3 \mathrm{mg} \mathrm{C} \mathrm{mg} \mathrm{Chl} a^{-1}$ hour $^{-1}$ in diatom-dominated communities along the outer shelf of Transects 200-400 and across the shelf of Transect 400 (Fig. 10a). The highest assimilation rate for diatoms ( $4.1 \mathrm{mg} \mathrm{C} \mathrm{mg}$ Chl $a^{-1}$ hour $^{-1}$ ) was estimated for low Chl $a$ waters over the UCDW intrusion at the shelf break on Transect 300 (Fig. 2a). Here, the $I_{k} s$ were $106 \pm 12 \mu$ Ein m $^{-2} \mathrm{~s}^{-1}$ and the water column C:N ratios averaged ca. 5.2. High biomass communities of diatoms (Fig. 9a), located over modified UCDW mid-shelf on Transect 300 (Fig. 2a), had similar C:N ratios

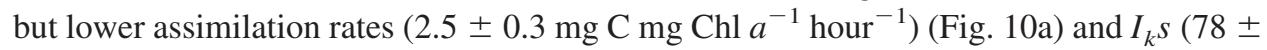
$18 \mu$ Ein $^{-2} \mathrm{~s}^{-1}$ ).

Within phytoflagellate communities, $\mathrm{P}_{\mathrm{MAX}}$ was $>4 \mathrm{mg} \mathrm{C} \mathrm{mg} \mathrm{Chl} a^{-1}$ hour $^{-1}$ (Fig. 10a) at two locations in modified UCDW (Fig. 2a) where diatoms accounted for $>40 \%$ of the community (Fig. 5a). One site was a localized region on the inner shelf of Transect 400 (Fig. 10a) at the frontal boundary of the cold coastal current waters (Fig. 2a). The other was mid-shelf on Transect 600 . Communities with $>70 \%$ phytoflagellate had the lowest photosynthetic potential, averaging $1.2 \mathrm{mg} \mathrm{C} \mathrm{mg} \mathrm{Chl} a^{-1}$ hour $^{-1}$ (Fig. 10a), and $I_{k}$ (46 $\mu$ Ein $\mathrm{m}^{-2} \mathrm{~s}^{-1}$ ). These observations suggest that phytoflagellates were low-light adapted 

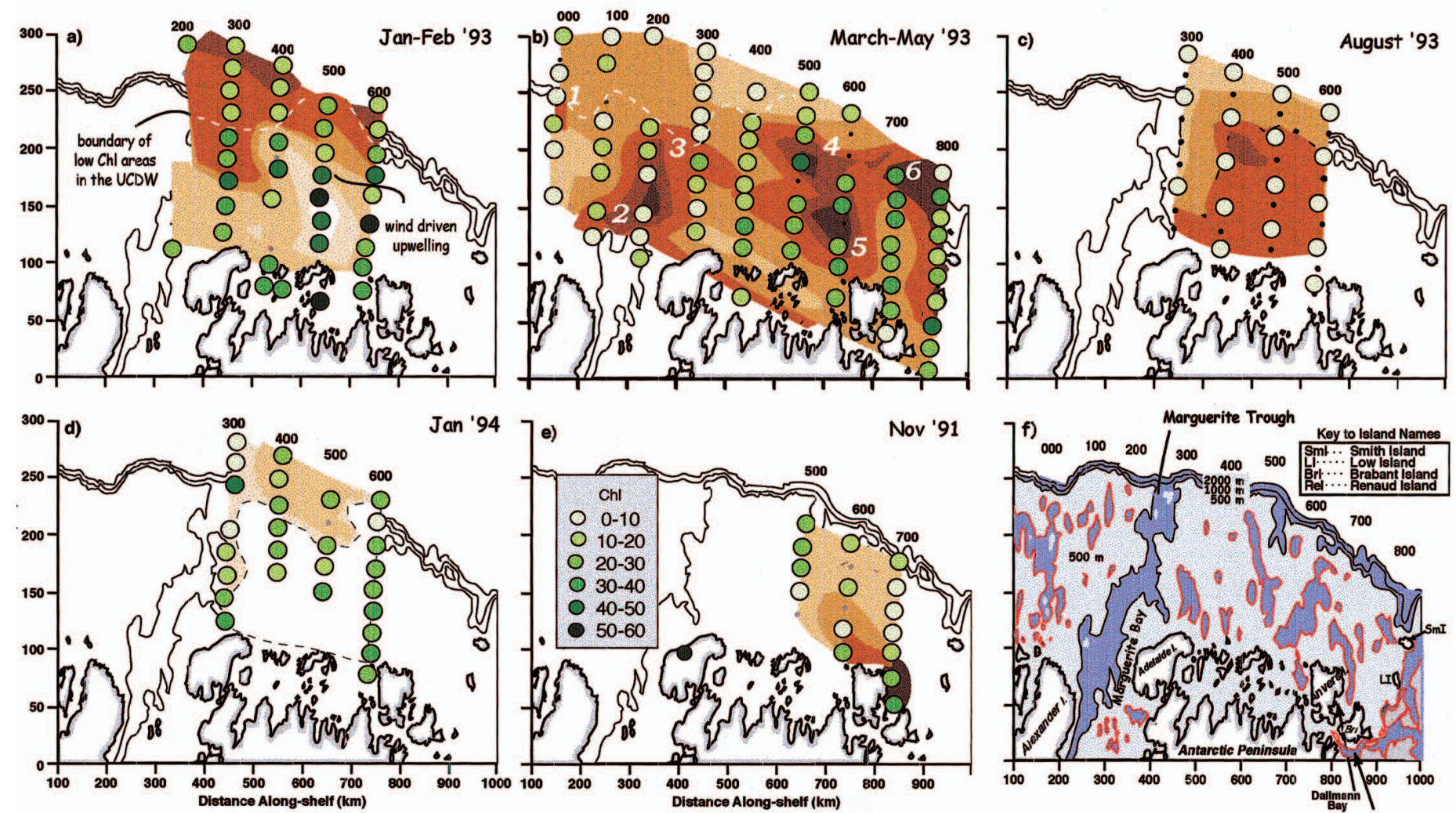

Figure 9. Comparison of total Chlorophyll $a$ biomass from 0 to $60 \mathrm{~m}$ (circles), relative to the distribution of diatom-dominated communities (shown as background, see Fig. 5), for (a) January-February 1993, (b) March-May 1993, (c) August-September 1993, (d) January-February 1994, and (e) November 1991. 

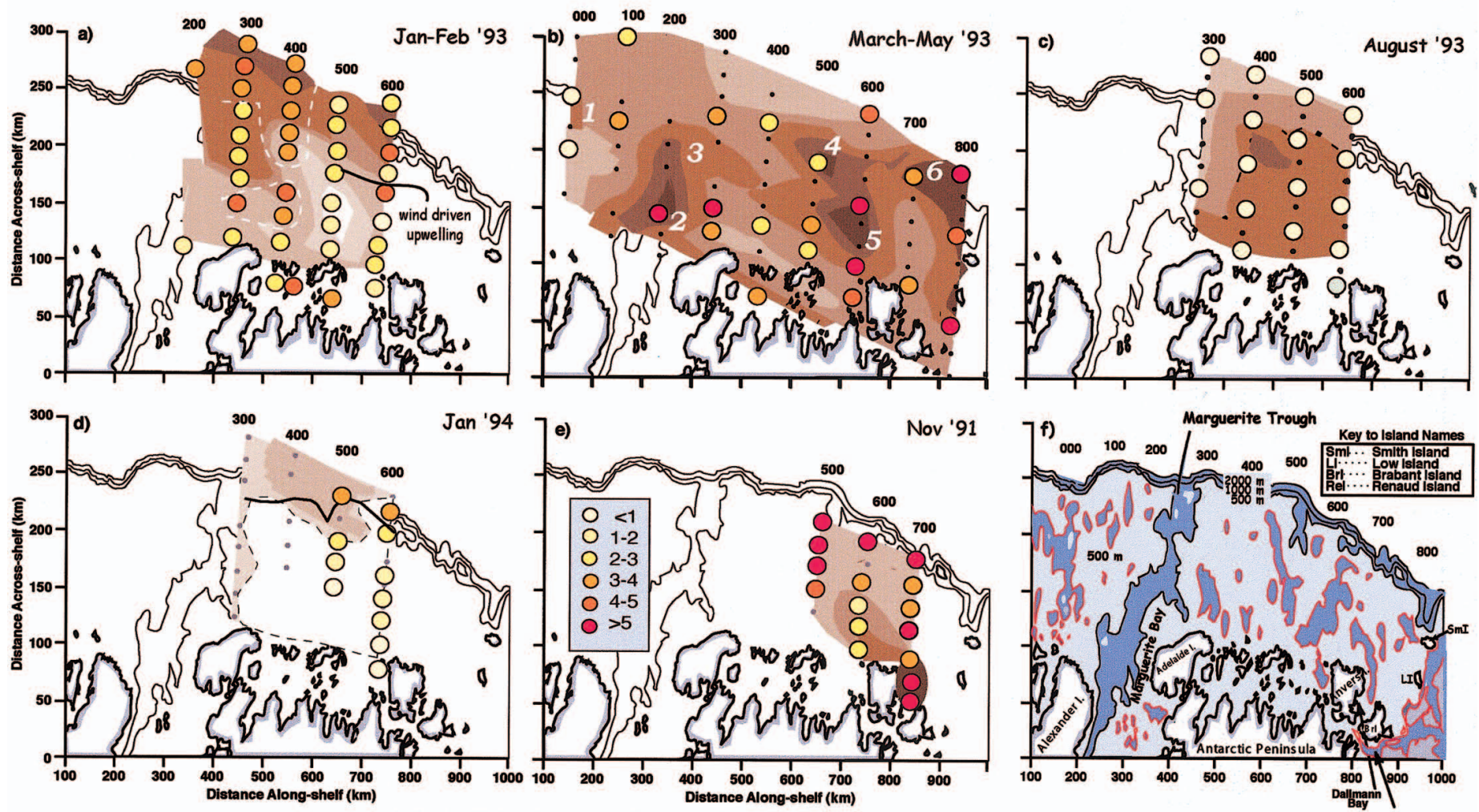

Figure 10. Comparison of average Chl-specific primary production for the upper $60 \mathrm{~m}$ (circles), relative to the distribution of diatom-dominated communities (shown as background, see Fig. 5), for (a) January-February 1993, (b) March-May 1993, (c) August-September 1993, (d) January-February 1994, and (e) November 1991. 
and that much of the chlorophyll $a$ accumulation at this site was not the result of cell growth but of pigment-dependent photoadaptation of slower growing cells. Since recently intruded waters were mixing in this region, it is not possible to use nutrient concentrations or $\mathrm{C}: \mathrm{N}$ values to estimate turnover times. However, the $>60 \%$ phytoflagellate communities at a greater distance from the new intrusion event routinely had C:N ratios of 6-8, values consistent with the view that these communities did not have a high growth potential prior to the event. If true, then new production would be much lower in phytoflagellate-dominated regions than in diatom-dominated regions than estimates based on chlorophyll $a$ and light penetration alone would predict (Moline and Prézelin, 2000).

From March to May of 1993, daylength shortened from 11 to 7.8 hours (Table 1). Production measurements were made only at stations the ship occupied during mid-day hours (Fig. 10b) POC and PON measurements were not made on this cruise. Diatoms dominated most water columns sampled in the northern region (Transects 500-900) and about half those sampled in the southern region (Transects 000-400) (Fig. 6). Chlorophyll $a$ was several fold higher in the northern than the southern region (Fig. 9b). $I_{k} s$ were

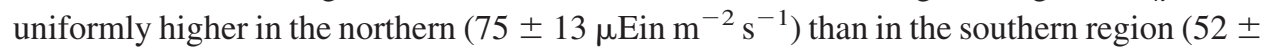
$11 \mu$ Ein $\mathrm{m}^{-2} \mathrm{~s}^{-1}$ ), perhaps a reflection on low-light photoadaption during the season of declining solar radiation. Compared to phytoflagellate-dominated communities, diatomdominated water columns had, on average, more than twice the chlorophyll $a$ and mid-day volumetric production rates (Table 7). Diatoms clearly accounted for most of the primary production of the WAP continental shelf in the fall of 1993. Chl-specific $\mathrm{P}_{\mathrm{MAX}}$ was $>5 \mathrm{mg}$ $\mathrm{C} \mathrm{mg} \mathrm{Chl} a^{-1}$ hour $^{-1}$ in diatom groupings 1, 5 and 6 (Fig. 10b), indicating enhanced rates of Chl-specific production was supported in WAP continental shelf waters throughout the austral fall and that it was unlikely that primary production was nutrient limited in the diatom patches sampled. Given its higher nutrient concentrations, higher $\mathrm{Si}(\mathrm{OH})_{4}: \mathrm{NO}_{3}$ ratios and lower $\mathrm{NO}_{3}: \mathrm{PO}_{4}$ ratio (Table 3), diatom group 1 appeared at an earlier stage of an UCDW event or 'younger' than diatom groupings 5 and 6 . Other areas had estimated assimilation rates of 3-5 $\mathrm{mg} \mathrm{C} \mathrm{mg} \mathrm{Chl} a^{-1}$ hour $^{-1}$, comparable to rates observed in diatom-dominated communities two months earlier in the austral summer. UCDW intrusions in the fall may play a key role in determining the amount and duration of enhanced primary production as winter approaches.

At the end of winter, in August 1993, chlorophyll $a$ (Fig. 9c), volumetric production (Fig. 8c) and assimilation rates (Fig. 10c) were uniformly low over the entire study region. The presence of an UCDW intrusion along Transect 300 was not coincident with enhanced primary production. Given that the MLD, nutrient availability and nutrient ratios in waters above the UCDW on Transect 300 were identical to those on Transect 400 (Table 4), it appeared the nutrient-rich UCDW water had not mixed upward significantly, perhaps because the presence of pack ice dampened mixing processes. Examination of vertical profiles (not shown) indicated that the identification of phytoflagellate-dominant communities in the upper $100 \mathrm{~m}$ was due primarily to their very high biomass in near-surface waters under the pack ice. Diatoms, while less abundant, dominated deeper phytoplankton 
communities. The presence of the warmer UCDW may be linked to the release of phytoplankton from the pack ice and, in this case, those ice communities were dominated by phytoflagellates (Phaeocystis spp.). If true, UCDW intrusions may also have a previously unrecognized role in the initiation of spring phytoplankton growth.

By the following summer, in January 1994, phytoflagellates dominated all water columns sampled and dinoflagellates had become a significant component of near-surface phytoplankton communities (Fig. 6). High chlorophyll $a$ accumulated on the inner part of Transect 600, the outer part of Transect 400, and in Marguerite Bay on Transect 300 (Fig. 9d). There were no UCDW intrusions. With the limited production data available (Fig. 8d, 10d), it appeared that production on Transect 600 was similar to that observed the prior summer when phytoflagellates were also present in this region of the study area.

Due to strong westerly winds, the pack ice was compressed during the November 1991 and the edge of the MIZ was especially sharp. Compared to phytoflagellate-dominated communities in the surface waters of the MIZ, the diatom-dominated communities located below the MIZ had ca 50\% more chlorophyll $a$ (Fig. 9e) and volumetric production (Fig. 8e). The diatom bloom in the open waters of Dallmann Bay had twice the POC concentrations as MIZ phytoplankton. The C:N ratio of the bloom approached 10 while the other two areas had $\mathrm{C}: \mathrm{N}$ ratios of 6-7 (data not shown). The lowest $\mathrm{C}: \mathrm{N}$ ratio of 4.3 was measured at the outer edge of Transect 700, which was influence by UCDW. Chl-specific rates of primary production (Fig. 10e) exceeded $5 \mathrm{mg} \mathrm{C} \mathrm{mg} \mathrm{Chl} a^{-1}$ hour $^{-1}$ in the ice-free diatom bloom, the MIZ where phytoflagellates dominated, and at the outer edge of Transect 700. Chl-specific rates of production were lowest, e.g. 2-3 mg C mg Chl $a^{-1}$ hour $^{-1}$, in diatom communities located in deep water under the ice on the inner Transect 600 .

\section{Discussion}

\section{a. UCDW intrusion development}

The hydrographic and phytoplankton community distributions observed during the four cruises in 1993 and 1994 showed patterns and progressions that are consistent with episodic forcing that resets the WAP continental shelf at irregular intervals. Periods of no or minimal intrusion effect, such as January 1994, were characterized by average $\mathrm{Si}(\mathrm{OH})_{4}: \mathrm{NO}_{3}$ ratios, high $\mathrm{NO}_{3}: \mathrm{PO}_{4}$ ratios, and dominance by phytoflagellates. In contrast, January 1993 was characterized by a new intrusion of UCDW along the outer WAP shelf which resulted in diatom-dominated phytoplankton communities. The effect of forcing by multiple intrusions, in differing stages of development, was represented by the diverse biological structure seen in March-May 1993. The August 1993 period was representative of an early stage intrusion. November 1991 provided a more limited characterization of the WAP during a time characterized by reduced or no UCDW intrusions. This time perhaps best illustrates the effect of the MIZ on phytoplankton community composition.

The space and time coverage of the WAP continental shelf afforded by the 1993 and 
1994 observations allowed characterization of the different stages associated with UCDW intrusions. New UCDW intrusions were confined to the outer shelf and were associated with temperatures of $1.8^{\circ} \mathrm{C}$ to $1.5^{\circ} \mathrm{C}$ at $200 \mathrm{~m}, \mathrm{Si}(\mathrm{OH})_{4}: \mathrm{NO}_{3}$ ratios of 2.8 to 3.5 at $200 \mathrm{~m}$, $\mathrm{NO}_{3}: \mathrm{PO}_{4}$ ratios of 10 to 12 , and low phytoplankton biomass with subsurface diatom communities beginning to develop. Once on the WAP continental shelf, the UCDW intrusion affected the phytoplankton community structure of the upper water column only if it upwelled and/or mixed upward and exchanged with the surface waters. The processes that allow mixing of UCDW include wind and topographic effects as well as diffusion and mixing across the permanent pycnocline (Smith et al., 1999; Smith and Klinck, 2002). The latter may be the dominant process during times when sea ice is present, such as in the winter (Smith and Klinck, 2002).

The start of an intrusion event was indicated by onshelf movement of the temperature maximum, decreasing $\mathrm{Si}(\mathrm{OH})_{4}: \mathrm{NO}_{3}$ ratios, increasing $\mathrm{NO}_{3}: \mathrm{PO}_{4}$ ratios, increasing diatom dominance, and a potential increase in Chlorophyll $a$. The presence of a well-developed UCDW intrusion on the WAP shelf was identified by movement of the temperature maximum of $1.6^{\circ} \mathrm{C}$ to $1.4^{\circ} \mathrm{C}$ to mid-shelf, $\mathrm{Si}(\mathrm{OH})_{4}: \mathrm{NO}_{3}$ ratios $<2.0$ at $200 \mathrm{~m}, \mathrm{NO}_{3}: \mathrm{PO}_{4}$ ratios of 12 to 14 , and decreased diatom dominance with dominance by phytoflagellates and other phytoplankton taxa increasing. The final stages of an old or waning UCDW intrusion occurred when the intruded water mass became stranded on the WAP shelf and was characterized by water temperatures of 1.35 to $1.5^{\circ} \mathrm{C}, \mathrm{Si}(\mathrm{OH})_{4}: \mathrm{NO}_{3}$ ratios that increased above 2.0, decreased $\mathrm{NO}_{3}: \mathrm{PO}_{4}$ ratios, and decreased diatom dominance with increased dominance by other phytoplankton taxa.

Areas that were not affected by intrusions of UCDW were characterized by temperatures $<1.3^{\circ} \mathrm{C}$ at $200 \mathrm{~m}$, variable nutrient ratios, variable nutrient concentrations, and mixed phytoplankton community assemblages. These conditions occurred in the areas affected by outflow from the Gerlache Strait and along the inner shelf where there is a southward flowing coastal current. Semi-enclosed bays, such as Dallmann Bay, are similar but may be dominated by diatoms or other taxa.

\section{b. Circulation patterns and phytoplankton communities}

A recurring pattern seen in the distribution of the temperature maximum below $200 \mathrm{~m}$ was onshelf intrusion of UCDW, which began at the shelf break in response to variability in the southern boundary of the ACC. The southern boundary of the ACC, determined by the location of the $1.8^{\circ} \mathrm{C}$ isotherm, was seen along the outer shelf in all of the times sampled (Fig. 2). The Antarctic Slope Front is absent along the WAP (Jacobs, 1991; Whitworth et al., 1998), which allows the southern boundary of the ACC to flow along the shelf break, thereby, allowing the oceanic water mass, UCDW, to intrude onto the continental shelf.

However, onshelf movement of UCDW did not occur all along the shelf break, rather it occurred at the outer end of Transects 200-300 (Figs. 2b-d) and Transects 600-700 (Figs. $2 \mathrm{a}-\mathrm{d})$. These are locations where the curvature of the shelf break is sufficient to allow 
onshore movement of UCDW (Dinniman and Klinck, 2004). It is in these regions that diatoms dominated the phytoplankton community structure (Fig. 7) and $\mathrm{Si}(\mathrm{OH})_{4}: \mathrm{NO}_{3}$ ratios were reduced (Fig. 3).

The intrusions moved onshelf and in some areas extended into the inner shelf region via deep across-shelf troughs that connect the inner and outer shelf regions. This across-shelf movement supports regions of enhanced diatom abundance, such as the one observed in March-May 1993 along the inner portion of Transect 200 (Fig. 4B). Transect 200 crosses Marguerite Trough, which allows UCDW to move from the outer shelf into Marguerite Bay (Klinck et al., 2004). Similarly, the high diatom abundances along the mid-shelf of Transect 600 (Fig. 4b, c) may be sustained by across-shelf movement of UCDW via the trough that extends from the shelf break towards Anvers Island.

The boundary between newly intruded UCDW and modified UCDW that covers the shelf below the permanent pycnocline is variable because of the episodic nature of the onshelf intrusions. This boundary moves further inshore as an intrusion event occurs. The phytoplankton community structure associated with this boundary is distinct and may be characterized by the presence of chlorophyll $b$, no to low diatoms biomass, and dominance by phytoflagellates (Fig. 5). Thus, this phytoplankton assemblage represents a transitional community between oceanic and shelf populations.

The inner portion of the WAP is characterized by a southerly-flowing coastal current, which is characterized by low salinity and temperature, which produces a frontal boundary with shelf waters (Smith et al., 1999). This inner shelf current was best resolved during the March-May 1993 cruise (Fig. 2b). The phytoplankton assemblages associated with the inner shelf current were mixed, with no pattern of consistent dominance by any group (Figs. 5, 6).

Temperature and phytoplankton observations from the nearby vicinity of Anvers Island (inner-most part Transect 600) tended to be anomalous relative to adjacent observations. This area is affected by outflow from the Gerlache Strait and the phytoplankton communities likely result from different environmental conditions. Similarly, the large diatomdominated bloom observed in November 1991 in Dallmann Bay along the inner part of Transect 700 may be representative of an environment with special conditions.

\section{c. Temporal variations}

An important conclusion arising from the comparisons of the hydrographic and phytoplankton distributions observed in 1993 and 1994 is that phytoplankton community structure on the WAP is seasonally independent. What is observed on this shelf arises from episodic inputs of UCDW, the frequency of which is determined by variability in the southern boundary of the ACC relative to the WAP shelf break. In turn, variability in this boundary is driven by larger scale climate-related processes rather than local seasonal forcing.

The temperature and phytoplankton distributions from January 1994 showed no UCDW intrusions on the WAP shelf, mixed phytoplankton assemblages, and average nutrient 
ratios. These distributions likely represent a baseline state for the WAP continental shelf. It should be noted that these conditions were observed in the austral summer when conditions are optimal for biological production. Thus, intrusions of UCDW are needed to stimulate phytoplankton community development/succession and biological production (evidenced by changes in nutrient ratios) on the WAP continental shelf.

The occurrence and progression of an intrusion event in one area of the shelf is independent of intrusions that occur in other regions of the WAP shelf. Thus, at any given time one or more intrusions, in different stages of development, may be present on the WAP continental shelf. This can provide considerable spatial variability in production, which must be taken into account when attempting system-wide production estimates.

\section{d. Implications for non seasonal succession}

Phytoplankton community succession certainly occurs in Antarctic coastal waters as water columns stratify and nutrient limitation occurs (Moline and Prézelin, 1996a and references therein; Moline et al., 1997). However, this succession is subject to disruption by physical forcing events such as upwelling, wind mixing, and freshwater lenses produced by seasonal glacial ice melt that seal off the upper mixed layer (Moline and Prézelin, 1996a). In waters over the WAP continental shelf, the occurrence of UCDW intrusions, and subsequent upwelling and/or mixing at specific locations, provides an episodic and major disruption of ongoing phytoplankton community succession.

The UCDW intrusions force a resetting of the chemical system to one that assures the immediate development of diatom-dominated communities over whatever phytoplankton assemblages were present at the time of the event. Over the shelf, phytoplankton community succession from diatom-dominated to phytoflagellate-dominant communities, which eventually contain a strong dinoflagellate component, proceeds as the UCDW intrusion subsides and as water column stratification leads to nutrient limitation within the upper mixed layer. The degree of succession from diatoms to phytoflagellates depends upon the frequency of the physical forcing of UCDW intrusions. Thus, classic seasonal succession from spring diatoms to summer phytoflagellates would not be a good representation of phytoplankton community changes at the regional scale. Recognizing the role that the presence or absence of UCDW intrusion events have in structuring phytoplankton communities makes it possible to explain the complexity of the observed phytoplankton distributions on the WAP continental shelf.

\section{e. Implications for production and carbon partitioning}

Episodic resetting of the western Antarctic continental shelf waters to diatom-dominated communities, with enhanced biological production, can alter the partitioning of organic carbon and change food web dynamics. Environmental stress is initially low at the start of an UCDW intrusion event because nutrients are high. Little dissolved organic carbon (DOC) is produced as diatom growth accelerates and cells remain in log-phase growth (Hansell and Carlson, 2002). The DOC that is produced should be near Redfield ratios in 
composition and thus quite labile to microbial remineralization (Smith et al., 1998; Carlson et al., 1998, 2000; Carlson and Hansell, 2004). The majority of new organic carbon is as POC. However, this production may go unrecognized if the diatoms are advected off the shelf, if the UCDW intrusion sites are high grazing sites, and/or if the majority of UCDW-induced production occurs at a depth deeper than usually assumed in satelliteremote sensing algorithms (Moline and Prézelin, 2000).

With cessation of an UCDW intrusion event, diatoms face declining nutrient supply, resulting in less POC production and more DOC excretion. The C:N ratio of this DOC should be higher and have reduced lability (Hansell and Carlson, 2002), resulting in declining food quality of the diatom-dominated community. As diatoms enter senescence, they tend to aggregate and sediment out of the mixed layer. Thus, the frequency and duration of UCDW intrusion events can also play an important role in benthic community dynamics on the WAP shelf.

Phytoflagellates achieve dominance in UCDW-influenced waters that have been biologically processed by diatoms and thus contain lower nutrient concentrations. However, they are also abundant in high-nutrient waters not influenced by UCDW and unable to support diatoms, such as the outflow of the Gerlache Strait in March 1993 (Fig. 5b). Both types of nutrient sources may initially sustain phytoflagellate growth but the carrying capacity (biomass and/or potential primary production) of the UCDW-influenced waters may be significantly less. Antarctic phytoflagellates tend be nanoplankton communities where microbial loop dynamics may be of central importance to carbon cycling.

\section{f. Extensions to other regions}

This analysis shows that UCDW intrusions, with their subsequent biological effects, occur at other times of year and at other sites than described in Prézelin et al. (2000) for the austral summer of 1993. The extent to which patterns and distributions observed on the WAP continental shelf are general features of Antarctic coastal waters can be partially addressed by observations reported in other studies. Kang and Lee (1995) reported abrupt changes in phytoplankton taxonomic assemblages along two across-shelf transects made in February 1993 that extended from western Bransfield Strait to Drake Passage (Fig. 1). Diatom dominance of the phytoplankton biomass increased abruptly on the outer shelf and shelf break seaward of the islands at the western end of Bransfield Strait. The maximum in diatom abundance was at about $60 \mathrm{~m}$. The observations made by Kang and Lee (1995) only extended to $100 \mathrm{~m}$, but the areas where diatoms dominated coincided with warmer temperatures, high macronutrients, and reduced $\mathrm{Si}(\mathrm{OH})_{4}: \mathrm{NO}_{3}$ ratios (their Figs. 2 and 3). Kang and Lee (1995) speculated that the dominance of diatoms was related to regional hydrographic features and that it may be possible to use diatoms and other phytoplankton species as markers for specific water masses within hydrographic regimes.

As suggested by Prézelin et al. (2000), places where the Southern ACC Front (SACCF) nears the shelf edge are potential sites for UCDW intrusions. These sites are nonuniformly distributed around the Antarctic (Jacobs, 1991; Whitworth et al., 1998). Direct evidence 
for increased biological production in these regions is lacking because of the limited historical observations for Antarctic coastal waters. However, indirect evidence is provided by the distribution of regions of high concentrations of Antarctic krill (Everson and Miller, 1994) and the distribution of cetaceans (Tynan, 1998). These studies provide a qualitative correlation between areas where the SACCF nears the shelf edge, the shallowing of CDW, and enhanced biological production. These correspondences clearly warrant further study, given the implications of the results from this study.

In oceanic waters off the Antarctic continental shelf (see Fig. 1), UCDW upwelling was observed when leads in the sea ice were present in the MIZ (Prézelin et al., 1994). These open regions within the sea ice became diatom-dominated while Phaeocystis-dominated communities persisted under the sea ice. The $\mathrm{Si}(\mathrm{OH})_{4}: \mathrm{NO}_{3}$ ratio was initially high, indicating input of UCDW, and then decreased as the nutrients were used by the diatoms. Two UCDW upwelling events occurred within one month at this study area. This open-ocean upwelling of UCDW provides episodic inputs of nutrients to the upper water column, which potentially results in enhanced diatom growth and increased biological production. These observations indicate another mechanism for increasing the biological production of Antarctic waters that has yet to be fully quantified.

\section{Conclusion}

Beyond observations of the role of UCDW in the reproductive success of Antarctic krill (e.g. Hempel et al., 1979; Hofmann et al., 1992) and its potential importance for cetaceans (Tynan, 1998), the effect of this water mass on biological production of Antarctic continental shelf waters was not considered until the study by Prézelin et al. (2000). The analyses presented here extend those given in Prézelin et al. (2000) to show that UCDW is a primary determinant of phytoplankton community composition and production in WAP continental shelf waters, and that it is potentially important for the larger Antarctic system. These observations and analyses make it surprising that UCDW intrusions are only now being recognized as being important to the productivity of Antarctic waters. However, several factors likely contributed to the lack of recognition of this process.

Previous biological studies did not routinely measure phytoplankton community composition and typically focused on the upper $100 \mathrm{~m}$ of the water column (see Priddle et al. (1994) for a discussion), which does not capture the subpycnocline inputs of UCDW. Thus, the sampling strategies were such that the role of the deeper processes in controlling phytoplankton community structure in the upper water column would not be recognized. The weak stratification of Antarctic continental shelf waters allows tight coupling between deep and surface processes and this characteristic of the environment needs to be incorporated into future biological studies.

The phytoplankton communities that develop in response to UCDW intrusions are subsurface and are at depths that are not detectable by satellite-borne ocean color sensors. Thus, these episodic events are not represented in the existing ocean color measurements. 
An implication of this is that primary production and chlorophyll $a$ estimates made for Antarctic continental shelf waters from ocean color measurements will be underestimates.

The photosynthetic physiological measurements made in 1993 and 1994 show that high rates of primary production are the norm in areas affected by UCDW intrusions. Thus, the observed low biomass with relatively high growth potential likely reflects heavy grazing of a highly productive system and/or advective loss due to the ACC and shelf currents. Thus, chlorophyll $a$ estimates alone, which are the majority of the available measurements for Antarctic coastal waters, are not sufficient to describe the phytoplankton community growth potential. Not surprising, these measurements need to be constrained with coincident measures of primary production, grazing rates and grazer biomass estimates.

Subsurface intrusions and subsequent upwelling or upward mixing of oceanic waters have been observed in other regions, such as the southeastern U.S. continental shelf (Atkinson, 1977, 1985) and the east coast of Australia (Andrews and Gentien, 1982). Estimates of the nutrient and carbon fluxes associated with intrusion events on these continental shelves (e.g. Lee et al., 1991) show that these events account for a significant portion of organic matter production. On the southeastern U.S. continental shelf, phytoplankton production and biomass are $>10$ times higher within intrusions than surrounding resident shelf waters (Yoder, 1985). Lee et al. (1991) estimated that nitrogen flux associated with upwelled Gulf Stream-derived waters on the southeastern U.S. shelf could support production of ca 8 million tons of carbon per year, if all of the nitrogen was used. The potential of biological production associated with UCDW intrusions on the Antarctic continental shelf has yet to be factored into nutrient and carbon budgets constructed for this region. The data sets used in this study, while comprehensive, are not adequate to quantify exchange rates, particle transformations, and total production associated with UCDW events. Multidisciplinary studies that follow an intrusion event through its entire life cycle on the shelf are needed and must be flexible enough to adapt to a variable environment. Failure to do so will result in missing a major portion of the signal that is controlling biological production in Antarctic coastal waters.

Acknowledgments. The research was supported by the U. S. National Science Foundation, Division of Ocean Sciences grant number OCE-9911731 (EEH, JMK) and OCE-00-01800 (BBP), Office of Polar Programs grant numbers OPP-9618383 (EEH) and OPP-9614938 (BBP) and UCSB Chancellor Award (BBP). We thank the scientists and crews of the R/V Polar Duke and the RVIB N. B. Palmer for their expert assistance that allowed collection of high quality data sets. The hydrographic analyses were done using the computer resources and other facilities provided by the Center for Coastal Physical Oceanography at Old Dominion University. We thank Nicolas Boucher, Allen Matlick and Sandy Roll for their special contributions to the collection, analyses and modeling of the high quality production data set collected during these cruises. Dave Karl (University of Hawaii) kindly provided the inorganic nutrient data for the March-May 1993 cruise. Moe Gomez and Debbie Miller provided excellent assistance in data analyses and graphic preparations.

\section{REFERENCES}

Andrews, J. C. and P. Gentien. 1982. Upwelling as a source of nutrients for the Great Barrier Reef ecosystems: A solution to Darwin's question? Mar. Ecol. Prog. Ser., 8, 257-269. 
Atkinson, L. P. 1977. Modes of Gulf Stream intrusion into the South Atlantic Bight waters. Geophys. Res. Lett., 4, 583-586.

1985. Hydrography and nutrients of the southeastern U.S. continental shelf, in Oceanography of the Southeastern U.S. Continental Shelf, L. P. Atkinson, D. W. Menzel and K. A. Bush, eds., American Geophysical Union, Coastal and Estuarine Sciences, 2, Washington, DC, 77-92.

Bidigare, R. R., J. L. Iriarte, S.-H. Kang, D. Karentz, M. E. Ondrusek and G. A. Fryxell. 1996. Phytoplankton: quantitative and qualitative assessment, in Foundations for Ecological Research West of the Antarctic Peninsula, R. M. Ross, E. E. Hofmann and L. B. Quetin, eds., American Geophysical Union, Antarctic Research Series, 70, 173-198.

Boucher, N. P. and B. B. Prézelin. 1996. Spectral modeling of UV inhibition of in situ Antarctic primary production using a field-derived biological weighting function. Photochem. Photobiol., 64, 407-418. http://www.lifesci.ucsb.edu/eemb/labs/prezelin/

Carlson, C. A., H. W. Ducklow, D. A. Hansell and W. O. Smith, Jr. 1998. Organic carbon partitioning during spring phytoplankton blooms in the Ross Sea polyna and the Sargasso Sea. Limnol. Oceanogr., 43, 375-386.

Carlson, C. A. and D. A. Hansell. 2004. The contribution of dissolved organic carbon and nitrogen to biogeochemistry of the Ross Sea, in Biogeochemical Cycles of the Ross Sea, G. DiTullio and R. Dunbar, eds., American Geophysical Union, Antarctic Research Series, 78, 123-142.

Carlson, C. A., D. A. Hansell, E. T. Peltzer and W. O. Smith Jr. 2000. Stocks and dynamics of dissolved and particulate organic matter in the southern Ross Sea, Antarctica. Deep-Sea Res. II, 47, 3201-3226.

Dinniman, M. S. and J. M. Klinck. 2004. A model study of circulation and across shelf exchange on the west Antarctic Peninsula continental shelf. Deep-Sea Res. II (in press).

Everson, I. and D. G. M. Miller. 1994. Krill mesoscale distribution and abundance: results and implications of research during the BIOMASS Programme, in Southern Ocean Ecology: The BIOMASS Perspective, S. Z. El-Sayed, ed., Cambridge University Press, 129-143.

Goldman, J. C., D. A. Hansell and M. R. Dennett. 1992. Chemical characterization of three large oceanic diatoms: potential impact on water column chemistry. Mar. Ecol. Prog. Ser., 88, 257-270.

Hansell, D. A. and C. A. Carlson, eds. 2002. Biogeochemistry of Dissolved Organic Matter in the Ocean, Academic Press, San Diego, CA, 774 pp.

Hempel, I., G. Hempel and A. de C. Baker. 1979. Early life history stages of krill (Euphausia superba) in Bransfield Strait and Weddell Sea. Meeresfor., 27, 267-281.

Hofmann, E. E., J. E. Capella, R. M. Ross and L. B. Quetin. 1992. Models of the early life history of Euphausia superba-Part I. Temperature dependence during the descent-ascent cycle. Deep-Sea Res., 39, 911-941.

Hofmann, E. E. and J. M. Klinck. 1998. Thermohaline variability of the waters overlying the West Antarctic Peninsula continental shelf, in Ocean, Ice, and Atmosphere Interactions at the Antarctic Continental Margin, S. Jacobs and R. Weiss, eds., American Geophysical Union, Antarctic Research Series, 75, 67-81.

Jacobs, S. S. 1991. On the nature and significance of the Antarctic Slope Front. Mar. Chem., 35, $9-24$.

Jeffrey, S. W., R. F. C. Mantoura and S. W. Wright, eds. 1997. Phytoplankton Pigments in Oceanography, UNESCO, Paris, France, $661 \mathrm{pp.}$

Johnson, K. S., R. L. Petty and J. Thomsen. 1985. Flow injection analysis for seawater macronutrients, in Mapping Strategies in Chemical Oceanography, A. Zirino, ed., Advances in Chemistry Series, 209, 7-30.

Kang, S.-H. and S.-H. Lee. 1995. Antarctic phytoplankton assemblage in the western Bransfield Strait region, February 1993: composition, biomass and mesoscale distributions. Mar. Ecol. Prog. Ser., 129, 253-267. 
Kim, H.-C., E. Hofmann, B. B. Prézelin and W. O. Smith, Jr. 2003. Estimation of primary production and carbon flux in Antarctic coastal waters: A modeling study. Abstract for "A Sea of Change: JGOFS Accomplishments and the Future of Ocean Biogeochemistry" Washington DC, National Academy of Science. http://www.uib.no/jgofs/Publications/cd_roms/

Klinck, J. M. 1998. Heat and salt changes on the continental shelf west of the Antarctic Peninsula between January 1993 and January 1994. J. Geophys. Res., 103, 7617-7626.

Klinck, J. M., E. E. Hofmann, R. C. Beardsely, B. Salihoglu and S. Howard. 2004. Water mass properties and circulation on the west Antarctic Peninsula continental shelf in austral fall and winter 2001. Deep-Sea Res. II (in press).

Klinck, J. M. and R. C. Smith. 1994. Oceanographic data collected aboard RV Polar Duke, August-September 1994, CCPO Technical Report No. 94-01, Center for Coastal Physical Oceanography, Old Dominion University, $152 \mathrm{pp}$.

Lascara, C. M., R. C. Smith, D. Menzies and K. S. Baker. 1993a. Oceanographic data collected aboard the R/V Polar Duke November 1991, CCPO Technical Report No. 93-01, Center for Coastal Physical Oceanography, Old Dominion University, 95 pp.

- 1993b. Oceanographic data collected aboard the R/V Polar Duke January-February 1993, CCPO Technical Report No. 93-02, Center for Coastal Physical Oceanography, Old Dominion University, 307 pp.

Lascara, C. M., E. E. Hofmann, R. R. Ross and L. B. Quetin. 1999. Seasonal variability in the distribution of Antarctic krill, Euphausia superba, west of the Antarctic Peninsula. Deep Sea Res. I, 46, 951-984.

Lee, T. N., J. A. Yoder and L. P. Atkinson. 1991. Gulf Stream frontal eddy influence on productivity of the southeastern U.S. continental shelf. J. Geophys. Res., 96, 22,191-22,205.

Mizerek, T. M. and B. B. Prezelin. 2004. Diel periodicity of photosynthesis compared for diatomand phytoflagellate-dominated communities in the shelf water of the West Antarctic Peninsula. ASLO Conference, Hawaii, 108.

Moline, M. A. and B. B. Prézelin. 1996a. Long term modeling and analyses of physical factors regulating variability in coastal Antarctic phytoplankton, in situ productivity and taxonomic composition over subseasonal, seasonal, and inter-annual timescales. Mar. Ecol. Prog. Ser., 145, 1443-160. www.lifesci.ucsb.edu/eemb/labs/prezelin/publications.html

_ 1996b. High-resolution time-series data for 1991/1993 primary production and related parameters at a Palmer LTER coastal site: Implications for modeling carbon fixation in the Southern Ocean. Polar Biol., 17, 39-53. www.lifesci.ucsb.edu/eemb/labs/prezelin/publications.html

2000. Optical fractionation of chlorophyll and primary production for coastal waters of the Southern Ocean. Polar Biol., 23, 129-136. www.lifesci.ucsb.edu/eemb/labs/prezelin/ publications.html

Moline, M. A., B. B. Prézelin, O. Schofield and R. C. Smith. 1997. Temporal dynamics of coastal Antarctic phytoplankton: Environmental driving forces through a 1991-1992 summer diatom bloom on the nutrient and light regime, in Antarctic Communities, B. Battaglia, J. Valencia and D. W. H. Walton, eds., Cambridge University Press, London, 62-72. www.lifesci.ucsb.edu/eemb/ labs/prezelin/publications.html

Moline, M. A., Schofield, O. and N. P. Boucher. 1998. Photosynthetic parameters and empirical modeling of primary production: a case study in the Antarctic Peninsula shelf. Ant. Sci., 10, 45-54.www.lifesci.ucsb.edu/eemb/labs/prezelin/publications.html

Neale, P. J. and P. J. Richerson. 1987. Photoinhibition and the diurnal variation of phytoplankton photosynthesis. I. Development of a photosynthesis-irradiance model from studies of in situ responses. J. Plankton Res., 9, 167-193.

Orsi, A. H., T. Whitworth III and W. D. Nowlin, Jr. 1995. On the meridional extent and fronts of the Antarctic Circumpolar Current. Deep-Sea Res. I, 42, 641-673. 
Parsons, T., Y. Maita and C. Lalli. 1984. A Manual of Chemical and Biological Methods for Sea Water Analysis. Pergamon Press, Oxford 173 pp.

Prézelin, B. B., R. R. Bidigare, H. A. Matlick, M. Putt and B. Ver Hoven. 1987. Diurnal patterns of size fractioned primary productivity across a coastal front. Mar. Biol., 4, 563-574. www.lifesci. ucsb.edu/eemb/labs/prezelin/publications.html

Prézelin, B. B., N. P. Boucher, M. Moline, E. Stephens, K. Seydel and K. Scheppe. 1992. PALMER LTER: Spatial variability in phytoplankton distribution and surface photosynthetic potential within the Peninsula grid, November 1991. Antarctic J. U. S., 27, 242-244. www.lifesci.ucsb.edu/ eemb/labs/prezelin/publications.html

Prézelin, B. B., N. P. Boucher and R. C. Smith. 1994. Marine primary production under the influence of the Antarctic ozone hole: Icecolors '90., in Ultraviolet Radiation and Biological Research in Antarctica, S. Weiler and P. Penhale, eds., American Geophysical Union, Washington, DC, 62, 159-186. www.lifesci.ucsb.edu/eemb/labs/prezelin/publications.html

Prézelin, B. B., E. E. Hofmann, J. M. Klinck and C. Mengelt. 2000. The linkage between Upper Circumpolar Deep Water (UCDW) and phytoplankton assemblages on the west Antarctic Peninsula continental shelf. J. Mar. Res., 58, 165-202. www.lifesci.ucsb.edu/eemb/labs/prezelin/ publications.html

Prézelin, B. B., E. E. Hofmann, J. M. Klinck and M. Moline. 2003. Recognizing shelf break forcing of phytoplankton community structure and enhanced biological productivity for Antarctic continental shelf waters. Abstract, "A Sea of Change: JGOFS Accomplishments and the Future of Ocean Biogeochemistry" Washington DC. http://www.uib.no/jgofs/Publications/ cd_roms/

Priddle, J., F. Brandini, M. Lipski and M. R. Thorley. 1994. Pattern and variability of phytoplankton biomass in the Antarctic Peninsula region: an assessment of the BIOMASS cruises, in Southern Ocean Ecology: the BIOMASS Perspective, S. Z. El-Sayed, ed., Cambridge University Press, 49-61.

Sievers, H. A. and W. D. Nowlin, Jr. 1984. The stratification and water masses at Drake Passage. J. Geophys. Res., 89, 10,489-10,514.

Smith, D. A., E. E. Hofmann, J. M. Klinck and C. M. Lascara. 1999. Hydrography and circulation of the west Antarctic Peninsula continental shelf. Deep-Sea Res. I, 46, 925-949.

Smith, D. A. and J. M. Klinck. 2002. Water properties on the west Antarctic Peninsula continental shelf: a model study of effects of surface fluxes and sea ice. Deep-Sea Res. II, 49, 4863-4889.

Smith, D. A., R. A. Locarnini, B. L. Lipphardt, Jr. and E. E. Hofmann. 1993a. Hydrographic data collected aboard RV Nathaniel B. Palmer, March-May 1993, CCPO Technical Report No. 93-04, Center for Coastal Physical Oceanography, Old Dominion University, 215 pp.

Smith, D. A., R. C. Smith and D. Menzies. 1993b. Oceanographic data collected aboard RV Nathaniel B. Palmer, March-May 1993, CCPO Technical Report No. 93-05, Center for Coastal Physical Oceanography, Old Dominion University, 265 pp.

Smith, R. C., B. B. Prézelin, K. S. Baker, R. R. Bidigare, N. P. Boucher, T. Coley, D. Karentz, S. Macintyre and H. A. Matlick. 1992. Ozone depletion, ultraviolet radiation and phytoplankton biology in Antarctic waters. Science, 255, 952-959. www.lifesci.ucsb.edu/eemb/labs/prezelin/ publications.html

Smith, W. O., C. A. Carlson, H. W. Ducklow and D. A. Hansell. 1998. Growth dynamics of Phaeocystis antarctica-dominated plankton assemblages from the Ross Sea. Mar. Ecol. Prog. Ser., 168, 229-244. http://www.int-res.com/abstracts/meps/v168/p229-244.html

Tynan, C. T. 1998. Ecological importance of the southern boundary of the Antarctic Circumpolar Current. Nature, 392, 708-710.

Whitworth, T. III, A. H. Orsi, S.-J. Kim, W. D. Nowlin, Jr. and R. A. Locarnini. 1998. Water masses 
and mixing near the Antarctic Slope Front, in Ocean, Ice, and Atmosphere Interactions at the Antarctic Continental Margin, S. Jacobs and R. Weiss, eds., Amer. Geophys. Union, Antarctic Research Series, 75, 1-27.

Wright, S. W., S. W. Jeffrey, R. F. C. Mantoura, C. A. Llewellyn, T. Bjornland, D. Repeta and N. Welschmeyer. 1991. Improved HPLC method for the analysis of chlorophylls and carotenoids from marine phytoplankton. Mar. Ecol. Prog. Ser., 77, 183-196.

Yoder, J. A. 1985. Environmental control of phytoplankton production on the southeastern U.S. continental shelf, in Oceanography of the Southeastern U.S. Continental Shelf, L. P. Atkinson, D. W. Menzel and K. A. Bush, eds., American Geophysical Union, Coastal and Estuarine Sciences, 2, Washington, DC, 93-103.

Received: 3 July, 2003; revised: 7 April, 2004. 